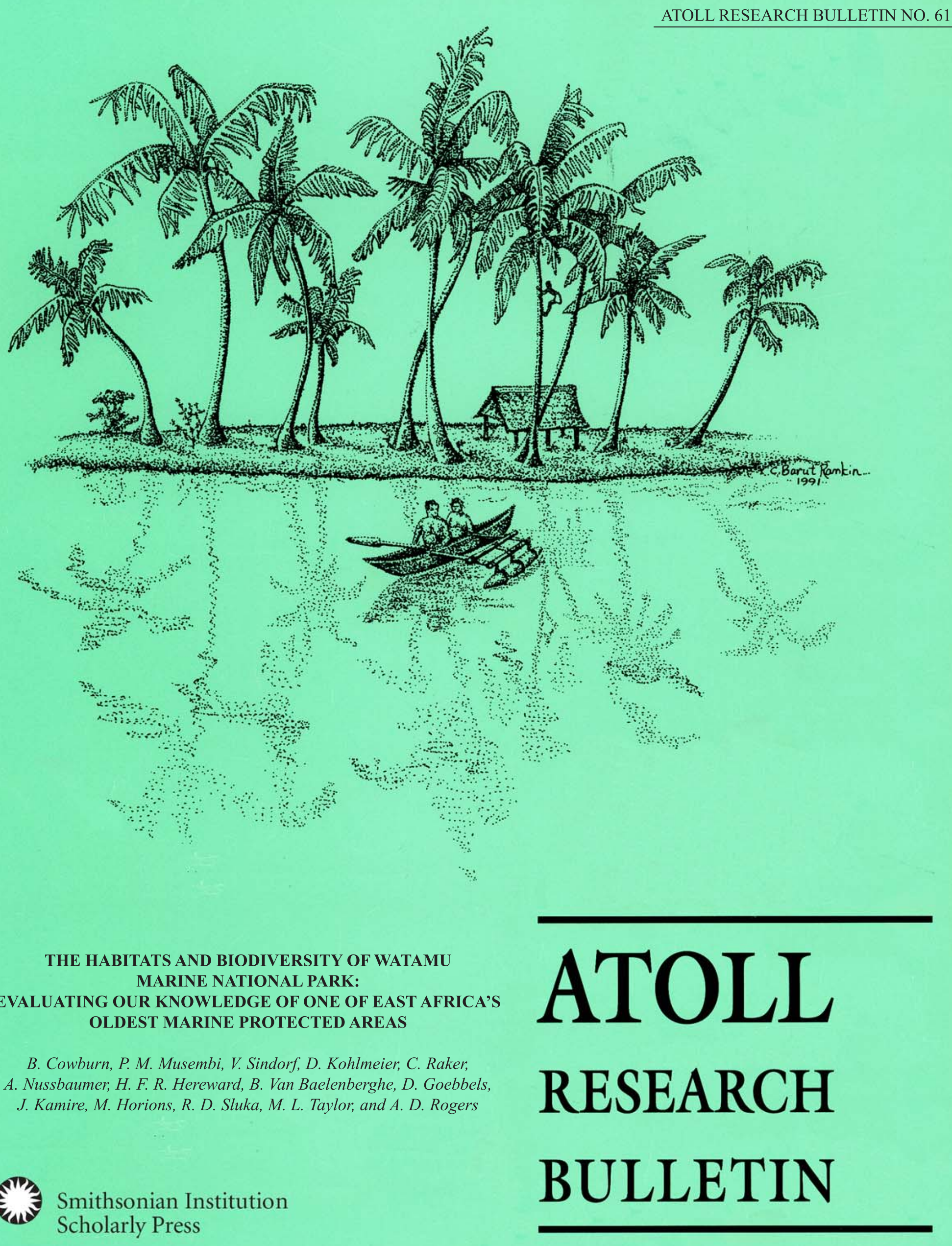




\title{
THE HABITATS AND BIODIVERSITY OF WATAMU MARINE NATIONAL PARK: \\ EVALUATING OUR KNOWLEDGE OF ONE OF EAST AFRICA'S OLDEST MARINE PROTECTED AREAS
}

\author{
B. Cowburn, P. M. Musembi, V. Sindorf, D. Kohlmeier, C. Raker, \\ A. Nussbaumer, H. F. R. Hereward, B. Van Baelenberghe, D. Goebbels, \\ J. Kamire, M. Horions, R. D. Sluka, M. L. Taylor, and A. D. Rogers
}

Atoll Research Bulletin No. 618 • 11 June 2018

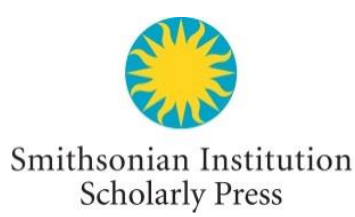

Washington, D.C. 
All statements made in papers published in the Atoll Research Bulletin are the sole responsibility of the authors and do not necessarily represent the views of the Smithsonian Institution or of the editors of the bulletin. Articles submitted for publication in the Atoll Research Bulletin should be original papers and must be made available by authors for open access publication. Manuscripts should be consistent with the "Author Formatting Guidelines for Publication in the Atoll Research Bulletin." All submissions to the bulletin are peer reviewed and, after revision, are evaluated prior to acceptance and publication through the publisher's open access portal, Open SI (http://opensi.si.edu).

Published by SMITHSONIAN INSTITUTION SCHOLARLY PRESS

P.O. Box 37012, MRC 957

Washington, D.C. 20013-7012

https://scholarlypress.si.edu/

The rights to all text and images in this publication are owned either by the contributing authors or by third parties. Fair use of materials is permitted for personal, educational, or noncommercial purposes. Users must cite author and source of content, must not alter or modify the content, and must comply with all other terms or restrictions that may be applicable. Users are responsible for securing permission from a rights holder for any other use.

ISSN: 0077-5630 (online) 


\title{
THE HABITATS AND BIODIVERSITY OF WATAMU MARINE NATIONAL PARK: EVALUATING OUR KNOWLEDGE OF ONE OF EAST AFRICA'S OLDEST MARINE PROTECTED AREAS
}

\author{
B. COWBURN ${ }^{1,2}$, P. M. MUSEMBI ${ }^{1}$, V. SINDORF ${ }^{1}$, D. KOHLMEIER ${ }^{1}$, C. RAKER ${ }^{1}$, \\ A. NUSSBAUMER ${ }^{1}$, H. F. R. HEREWARD ${ }^{1}$, B. VAN BAELENBERGHE ${ }^{1}$, D. GOEBBELS ${ }^{1}$, \\ J. KAMIRE ${ }^{1}$, M. HORIONS ${ }^{1}$, R. D. SLUKA ${ }^{1 *}$, M. L. TAYLOR ${ }^{3 *}$, and A. D. ROGERS ${ }^{2 *}$
}

\begin{abstract}
Watamu Marine National Park (WMNP) is one of the oldest no-take Marine Protected Areas (MPAs) in the world. Since its establishment in 1968, it has been the subject of a number of scientific studies as well as being exposed to range of modern anthropogenic threats to coastal marine habitats. The current state and conservation value of WMNP is documented in terms of habitat, biodiversity, and available scientific literature. Most of the 101 published references relating to WMNP focus on coral reef ecology, with less attention to biodiversity, socio-economics, or the ecology of non-coral reef habitats. The habitat map produced of WMNP is the first to show this level of detail and the only habitat map of a Kenyan MPA. Nine habitat categories were mapped, revealing that the most dominant habitat type by area is seagrass and the least is coral reef. Species lists were collected for fish, echinoderms, molluscs, crustaceans, corals, and seagrass, and species abundances were used to estimate total species richness, species diversity and sampling completeness. There were 18 species across all groups that fall into a category of conservation concern (other than Least Concern or Not Evaluated) on the IUCN Red List and 8 species found which are currently undescribed. This detailed case-study of marine biodiversity conservation in a less economically developed tropical nation emphasises the importance of non-coral habitats in the WMNP, such as seagrass beds, and the need for more research into the ecology and conservation importance of these habitats.
\end{abstract}

\section{INTRODUCTION}

Marine protected areas (MPAs) have increased threefold in the past decade, largely in response to Aichi Target $11^{4}$; to conserve $10 \%$ of marine areas through the use of protected areas and other spatial management measures by 2020 (Juffe-Bignoli et al. 2014). The purpose of MPAs varies from location to location, although broadly they are established for the protection of biodiversity and habitats, managing fisheries, promoting sustainable use of marine resources, and promoting tourism (Salm and Clark 2000). Various attempts have been made to assess how effective MPAs are as a conservation strategy (Wood et al. 2008, Lester et al. 2009, Fox et al. 2014). These assessments have shown broadly positive successes, such as maintenance of higher biomass of fish (Lester et al. 2009) and preventing coral loss (Selig and Bruno 2010). However, there is concern that many MPAs are too small (Mora et al. 2006), have ineffective management (Sale 2008), and do not share the benefits of MPAs equitably within local communities (Juffe-Bignoli et al. 2014). A common theme in these studies is the difficulty of assessing

\footnotetext{
${ }^{1}$ A Rocha Kenya, Plot 28, Beach Road, Watamu 80202, Kenya

${ }^{2}$ Department of Zoology, Tinbergen Building, South Parks Road, Oxford, OX1 3PS

${ }^{3}$ School of Biological Sciences, University of Essex, Wivenhoe Park, Colchester, CO4 3SQ

${ }^{*}$ These authors were joint supervisers of this project

${ }^{4}$ https://www.cbd.int/doc/strategic-plan/targets/T11-quick-guide-en.pdf
} 
MPA effectiveness, because of a paucity of information available for assessments (Wood et al. 2008, Juffe-Bignoli et al. 2014).

The Western Indian Ocean (WIO) is a biogeographically distinct region of the wider tropical Indo-Pacific realm (Richmond 2002, Obura 2012), which includes the tropical East African coastline from the Red Sea to South Africa, and islands such as the Seychelles, Mauritius and Madagascar. It has moderately high biodiversity with over 60 genera of corals (Obura 2012) and 2000 species of fish (Richmond 2002), but compared to other shallow tropical marine areas it has received much less scientific attention (Sheppard 2000). The WIO has a long history of marine conservation, with many countries establishing their first MPAs in the 1960s (Wells et al. 2007). In Kenya there are four no-take marine 'parks' (total area $-55 \mathrm{~km}^{2}$ ) where fishing and all forms of extraction are forbidden, and six 'reserves' $\left(735 \mathrm{~km}^{2}\right)$ where fishing and other activities are regulated for sustainability (Figure 1), meaning that Kenya currently protects $8.7 \%$ of its continental shelf (Wells et al. 2007). Continuous fringing coral reef is present along the southern coastline of the country, but because of local geology and currents it is more patchily distributed in the north (McClanahan 1988; Figure 1). The MPA network in Kenya protects coral reefs, seagrass beds, mangrove areas and a range of intertidal habitats including mudflats, beaches, and rocky shorelines (Semesi 1998, Gullström et al. 2002, Nordlund 2012, McClanahan 2014).

Watamu Marine National Park (WMNP) covers a $10 \mathrm{~km}^{2}$ section of the lagoon and back-reef south of Watamu village (Figure 2), and includes all habitats between the dune vegetation to the reef crest. At its southern end a tidal inlet formed by Mida Creek creates a deeper channel and break in the reef-crest. Mida Creek contains $32 \mathrm{~km}^{2}$ of mangrove forests and rich tidal mudflats, a crucial habitat for wading birds. Both Mida Creek and the fore-reef slope are outside of the park, but are part of the Watamu-Malindi Marine National Reserve $\left(164 \mathrm{~km}^{2}\right)$, which extends $20 \mathrm{~km}$ to the north and also encompasses Malindi Marine National Park (Figure 1). WMNP was created in 1968 and the WatamuMalindi Marine National Reserve was declared a UNESCO biosphere reserve in 1979. The park is officially managed by Kenya Wildlife Service (KWS), who are responsible for the management and conservation of both marine and terrestrial parks in Kenya, with some cross over in responsibility with the Ministry of Fisheries (Muthiga 2009). The park saw a steady increase in tourists from the 1970s to present (Muthiga 2009) and now tourism is the major component of the local economy (Carter 2012). There are three NGOs carrying out marine conservation in WMNP, through data collection, community relationships and links with tourism. Watamu Turtle Watch works with turtles and has a rehabilitation centre near the beach, while Watamu Marine Association plays an important role in connecting local marine stakeholders, tourist organisations and government bodies to discuss conservation issues. A Rocha Kenya's marine programme was established in 2010, focussing on biodiversity and ecological research in MPA habitats, with a major component of its data collection on the being presented in this paper.

Although WMNP has been protected for 50 years, there has never been a comprehensive inventory of species or a map documenting the range of habitats found in its boundaries. Without this information it is difficult to identify conservation priorities or develop management actions and risks a 'sliding baseline' in our understanding of the biodiversity and habitats found there (Knowlton and Jackson 2008). The aim of this paper is to collate all the historical information available for WMNP and construct a contemporary baseline for the park. Specifically, we aim to:

- Compile all the existing literature available for the park to identify where historical data are available and highlight gaps in our understanding of WMNP.

- Produce a habitat map for the park to demonstrate the range and extent of the habitats being protected.

- Assess the biodiversity of major taxa in the different habitats of the park as a first step towards understanding the biota of WMNP as an integrated system. 


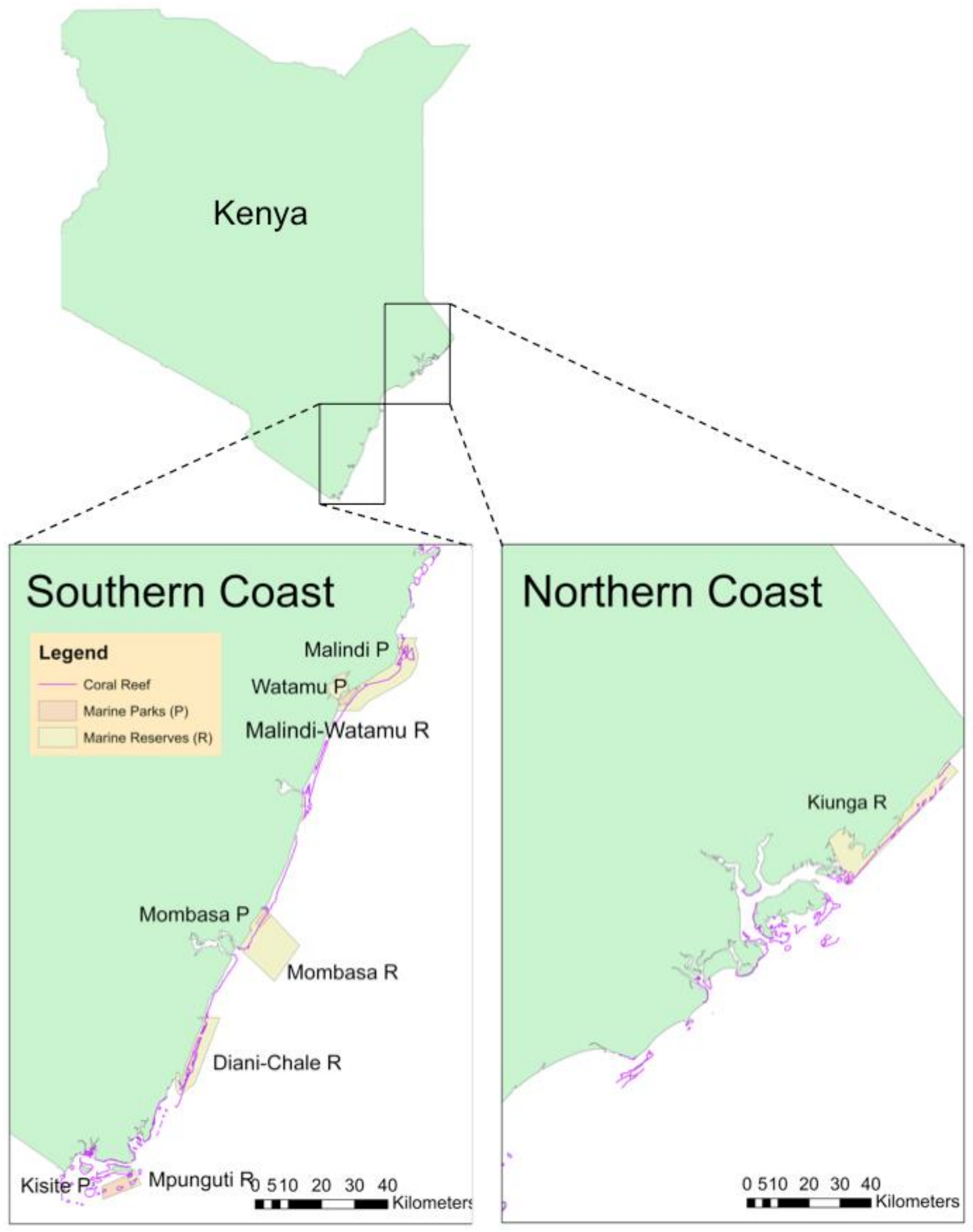

Figure 1. A map of Kenya's coastline and coral reefs, showing the locations of MPAs. 


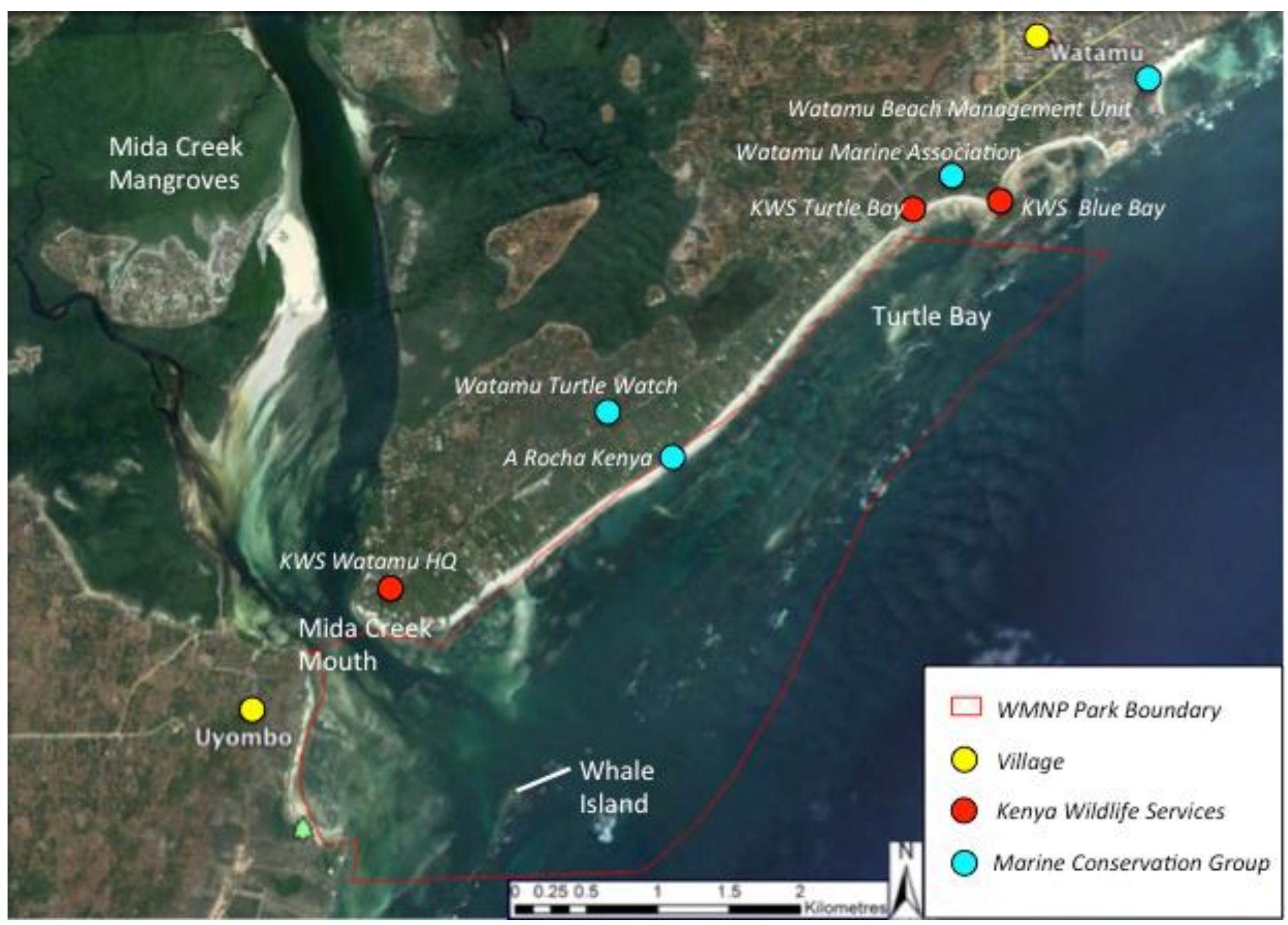

Figure 2. Satellite image of WMNP used in habitat mapping, showing the locations of Kenya Wildlife Services, conservation groups and main villages surrounding the MPA. Image date: 20.1.11. Image accessed from Google Earth. 


\section{METHODS}

\subsection{Literature review}

A detailed bibliography of all published papers, grey literature, and reports was compiled by Muthiga and Kawaka (2010) for all marine protected areas in Kenya. An initial bibliography for WMNP was compiled from this, augmented with more recent records,and annotated (Appendix 1). The geographical scope of each reference was defined as 'Watamu' if WMNP was the only study site, 'Kenya' if WMNP was one of several sites in the country or 'International' for any study including data from outside of Kenya.

\subsection{Habitat mapping}

Habitat classifications were chosen a priori based on similar habitats defined in Jones (1969). These were based on dominant benthic component and divided among the littoral zone as follows:

- Subtidal

- Coral reef: Holocene carbonate formations with $>5 \%$ coral cover

- Subtidal rock: Pleistocene carbonate formation with $<5 \%$ coral cover

- Subtidal sand: Mobile carbonate sand deposits

- Subtidal seagrass: Benthos with $>50 \%$ covering of seagrass

○ Mixed: Benthos with $<50 \%$ seagrass mixed with rubble, macroalgae and bare substrate

- Intertidal - Between Mean Low Water Spring (MLWS) and Mean High Water Spring (MHWS)

○ Tidepool: Eroded pleistocene carbonate platforms containing pools

○ Beach: Intertidal sand

○ Intertidal seagrass: Intetidal areas with $>50 \%$ seagrass cover

- Supralittoral fringe

○ Islands, dunes and cliffs: Any area above MHWS

Ground-truthing surveys of subtidal habitats were conducted by dividing the park into zones (2$3 \mathrm{~km}^{2}$ each) and systematically traversing from the low tide mark to the reef crest in roughly parallel lines, with an observer in the water and a second person on a boat recording GPS positions. Notes were made on the dominant benthic substratum and particular attention was paid to the presence of patch reefs. Subtidal ground-truthed waypoints were plotted onto a satellite image of WMNP (Figure 2) and overlain on the map. Habitat polygons were created through 'heads up digitising' (ESRI 2017) whereby the mapper uses visible colour patches, the groundtruthed points and knowledge of the area to manually draw habitat patches. Intertidal habitats were mapped by recording tracks on a GPS by walking around habitat patches at the lowest tide of each tidal cycle (i.e. MLWS). Intertidal polygons were converted from these GPS tracks. Habitat layers and maps were produced using ArcMap 10.0 (ESRI 2010).

\subsection{Biodiversity}

Species lists were collected for fish, echinoderms, molluscs, crustaceans, and seagrass, but corals were identified to genus level. These lists are based on both quantitative sampling and chance incidental observations from 2011-2014 when the lead author was based at A Rocha Kenya's marine programme. Twelve affiliates of the marine programme contributed to data 
collection (Table 1). The eight intertidal and subtidal habitats defined for habitat mapping were condensed into three 'zones' to structure data collection: 'coral reef', 'intertidal' (beach, tidepool and intertidal seagrass), and non-reef 'subtidal' (rocky reef, sand, seagrass and mixed). The supralittoral zone, composed of dunes, rocky cliffs and islands in the park was not surveyed for biodiversity.

Table 1. Data collection for fish, echinoderm, mollusc, crustacean, seagrass, and coral diversity by zone. Incidental and quantitative data collection (blue) and incidental records only (yellow) are indicated. Data collectors include Benjamin Cowburn (BC), Robert Sluka (RS), Dawn Goebbels (DG), Victoria Sindorf (VS), Cassie Raker (CR), Peter Musembi (PM), Hannah Hereward (HH), Aline Nussbaumer (AN), Mattias Horions (MH), Jack Kamire (JK), Benjamin van Baelenberghe (BB) and Dorothea Kohlmeier (DK). All collectors are affiliated with A Rocha Kenya's marine programme.

\begin{tabular}{|l|l|l|l|}
\hline \multirow{2}{*}{ Taxon } & \multicolumn{2}{|l|}{ Zone } & Subtidal \\
\cline { 2 - 4 } & Coral Reef & Intertidal & CR, BC \\
\hline Fish & BC, RS, DG & VS, BC & Not sampled \\
\hline Coral & BC & BC, VS, PM, BB & BC \\
\hline Echinoderms & PM, AN, BC & CR, PM & BC \\
\hline Molluscs & PM, HH, AN, BC & MH, JK, PM & Not sampled \\
\hline Crustacea & HH & HH & DK \\
\hline Seagrass & Not sampled & DK & \\
\hline
\end{tabular}

All of the sampling was done visually; cryptic and infaunal (burrowing) species were not included. For some taxa (e.g. Molluscs and Echinoderms) this will have missed a significant number of species actually found in the park. Quantitative data were collected for all fish and non-cryptic echinoderms and molluscs $(>1 \mathrm{~cm})$ in coral reef and intertidal areas. In subtidal areas only fish were assessed quantitatively (Table 1). Data were collected at the six lagoonal patch reefs between 1 to $8 \mathrm{~m}$ below mean low water (MLW) using randomly placed belt transects. Fish transects were $40 \times 5 \mathrm{~m}\left(200 \mathrm{~m}^{2}\right)$ and for echinoderms and molluscs, $20 \times 2 \mathrm{~m}\left(40 \mathrm{~m}^{2}\right)$. Biodiversity data from intertidal areas were collected on rocky platforms $(\sim 1 \mathrm{~m}$ above MLW) at regular intervals along the beach. Intertidal areas were sampled with $1 \mathrm{~m}^{2}$ quadrats placed randomly on the platforms, for all taxa sampled (Sindorf et al. 2015). Subtidal fish data were collected in $5 \mathrm{~m}$ wide belt transects running in 4 lines that traverse the park at regular intervals ( $\sim 2 \mathrm{~km}$ apart) from the beach to the reef crest.

Incidental records for various taxa were collected based on chance observations reported by A Rocha affiliates (Table 1). New species were added to the relevant species list and, where possible, a location and date. Incidental records were made for fish, corals, molluscs, echinoderms, seagrass and crustaceans. Intertidal incidental records also include beach and intertidal seagrass habitats, which were not surveyed during quantitative intertidal sampling. All species lists were annotated with IUCN Red List status of species classed as 'Near Threatened' or greater (http://www.iucnredlist.org/) and the fish list was annotated with species' biogeographical affinity (Froese and Pauly 2015). Quantitative data were analysed to produce estimates of species abundance, total species richness, species diversity and community similarity between zones, using ' $R$ ' packages BiodiversityR and Vegan (Kindt and Coe 2005). The sampling completeness of quantitatively surveyed taxa in each zone (coral reef, intertidal and subtidal) was determined using individual-based rarefaction curves and by calculating total richness estimates. Four common total richness estimates were used: Chao, Jackknife 1, Jackknife 2 and Bootstrap (Kindt and Coe 2005) to give a range of estimated values. 


\section{RESULTS}

\subsection{Literature review}

A total of 101 unique references were found (Figure 3 and Appendix 1), with topics varying from subsistence economics (Versleijin 2001) to turtle endogeny (Watson 2006). Of the references that present biological information gathered in WMNP, 14 include data from the intertidal zone, 14 from the subtidal zone and the majority, from coral reefs. There were 43 references focussed on Watamu alone, 51 where information from WMNP was included with other sites in Kenya, and seven with sites internationally (Appendix 1).

The first publication to include data from Watamu (Isaac and Isaac 1968) reviewed marine botany for the entire Kenyan coast. Shortly afterward the Bangor University expedition in 1969 collected specific information about the newly created park and produced 8 publications, largely around lead editor David Jones' interest in isopods (Crustacea: Isopoda e.g. Jones 1971), but also including the first comprehensive baseline data available for the park's biodiversity and ecology (Jones 1969). A research expedition from the University of Nijmegen, in the Netherlands, carried out a second review of the park in 1982, focussing on coral health and sedimentation from terrestrial erosion (Blom et al. 1985, van Katwijk et al. 1993). In 1987 the Kenyan Wildlife Conservation Society (WCS) group, headed by Dr. Timothy McClanahan, began regular ecological monitoring of Kenya's MPAs. To date, with nearly 30 years of annual data collection, WCS have published 45 pieces of work using data from Watamu, including some of the most widely cited coral reef ecology and conservation references in current scientific literature (e.g. McClanahan et al. 2001, McClanahan et al. 2007). This is especially true post1998, when the devastating mass bleaching and mortality of corals in Watamu and across the world, spurred the study of coral reef ecology and conservation in the face of human-driven climate change.

More recently the government bodies Kenya Wildlife Services (KWS) and Kenya Marine and Fisheries Research Institute (KMFRI) began monitoring and conducting marine research. In partnership with KWS, A Rocha Kenya began its marine programme in 2010. There have been 14 papers and reports from this group (available online at http://kenya.arocha.org/work/scientificresearch/reports/) relating to various aspects of marine biodiversity and ecology.

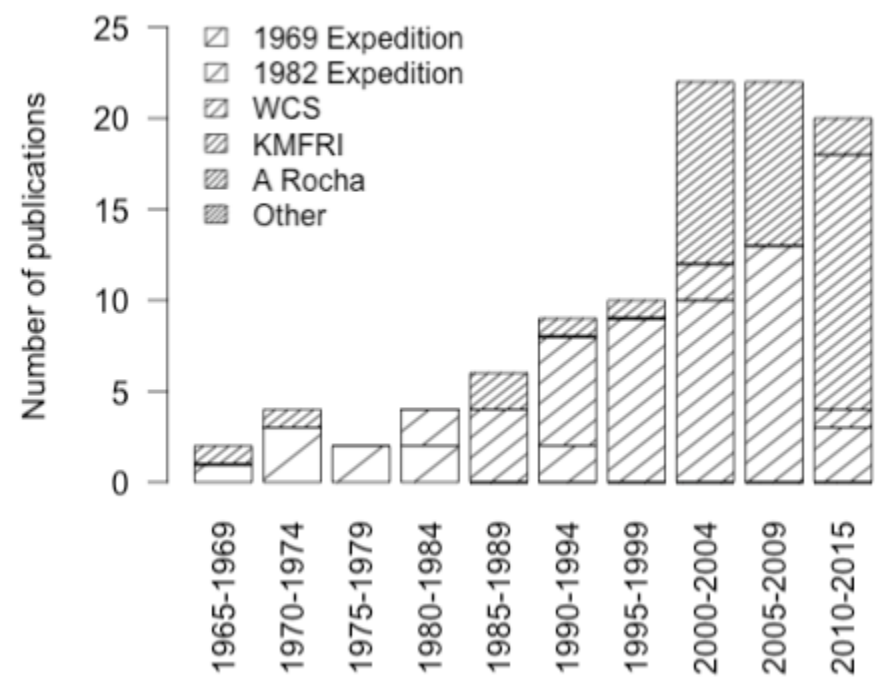

Figure 3. Publication by research group in WMNP from 1968-2015, including records from the 
1969 University of Bangor expedition, 1982 University of Nijmegen expedition, Wildlife Conservation Society, Kenya Marine and Fisheries Research Institute (KMFRI) and A Rocha Kenya

\subsection{Distribution of habitats in WMNP}

Habitats were mapped in $8.35 \mathrm{~km}^{2}\left(83.5 \%\right.$ of $\left.10 \mathrm{~km}^{2}\right)$ of the park's area. Areas of the MPA beyond the reef crest were not surveyed because of difficulty in accessing these rougher waters and in the reliability of detection of habitat patches on satellite imagery. An estimated $82 \%$ of the mapped area is subtidal, $13 \%$ is intertidal and 5\% is the supralittoral fringe (Table 2). Subtidal seagrass is the most dominant component of the park covering nearly $40 \%$ of the benthos found in calm sheltered waters $<3 \mathrm{~m}$ deep. On shallow reef crest higher wave energy has created a mixed habitat of seagrass, rubble and occasional coral colonies (14\% of area) and in deeper channels $(3-10 \mathrm{~m})$ sandy carbonate deposits dominant the benthos $(26 \%)$. Coral reef was the smallest habitat covering an estimated $1 \%$. Hard substrata (either rock or coral) cover just $5.3 \%$ of intertidal and subtidal areas. Lines of exposed Pleistocene limestone run parallel to the shore, along the beach edge forming the numerous tide-pool patches and also along the reef crest and through the lagoon forming subtidal rocky reefs (Figure 4). Other areas were characterised by sandy and rubble substrata with extensive seagrass growth in shallower $(<4 \mathrm{~m})$ depths.

Table 2. Area covered by different habitat in WMNP in $\mathrm{km}^{2}$ and percentage of the mapped area

\begin{tabular}{|l|l|l|}
\hline Habitat & Area in $\mathbf{k m}^{\mathbf{2}}$ & \%of mapped area \\
\hline Littoral & 0.418 & 5.0 \\
\hline Coral & 0.085 & 1.0 \\
\hline Tidepool & 0.216 & 2.6 \\
\hline Subtidal rock & 0.144 & 1.7 \\
\hline Beach & 0.495 & 5.9 \\
\hline Subtidal sand & 2.185 & 26.2 \\
\hline Intertidal seagrass & 0.359 & 4.3 \\
\hline Subtidal seagrass & 3.292 & 39.4 \\
\hline Mixed subtidal & 1.154 & 13.8 \\
\hline
\end{tabular}

Most coral reef habitat is also found in a line parallel to shore on the seaward slope of a channel (3-6m deep) that stretches along the central section of the park, including Coral Gardens, the most popular tourist spot (Figure 4). This habitat consists of a chain of small (10-50m long) lagoonal patch reefs, featuring large $(>2 \mathrm{~m})$ Porites colonies. At the landward edge of these patch reefs, the reef rises above the $\sim 1 \mathrm{~m}$ deep sandy/seagrass habitat to the MLW. Other reefs are found at Turtle Reef and Uyombo, where smaller channels near the reef crest support reef growth on slopes $\left(\sim 30^{\circ}\right)$ extending to $8-10 \mathrm{~m}$ deep (Figure 4$)$. These areas are similar to the main reef chain, but have greater water circulation and wave exposure from the ocean, encouraging some fore-reef species (e.g. Manta sp.) to foray into these habitats. Much of the intertidal area is beach (43\%), with significant areas of intertidal seagrass found near Uyombo village. Rocky tidepool habitats are most common near the northern edge of Mida Creek channel and on the northern shoreline near Turtle Bay. Limestone platforms (0.5-1m above mean low water) are eroded in complex honeycomb patterns, which has created a network of pools and underground tunnels, some of which are large enough to snorkel in. 


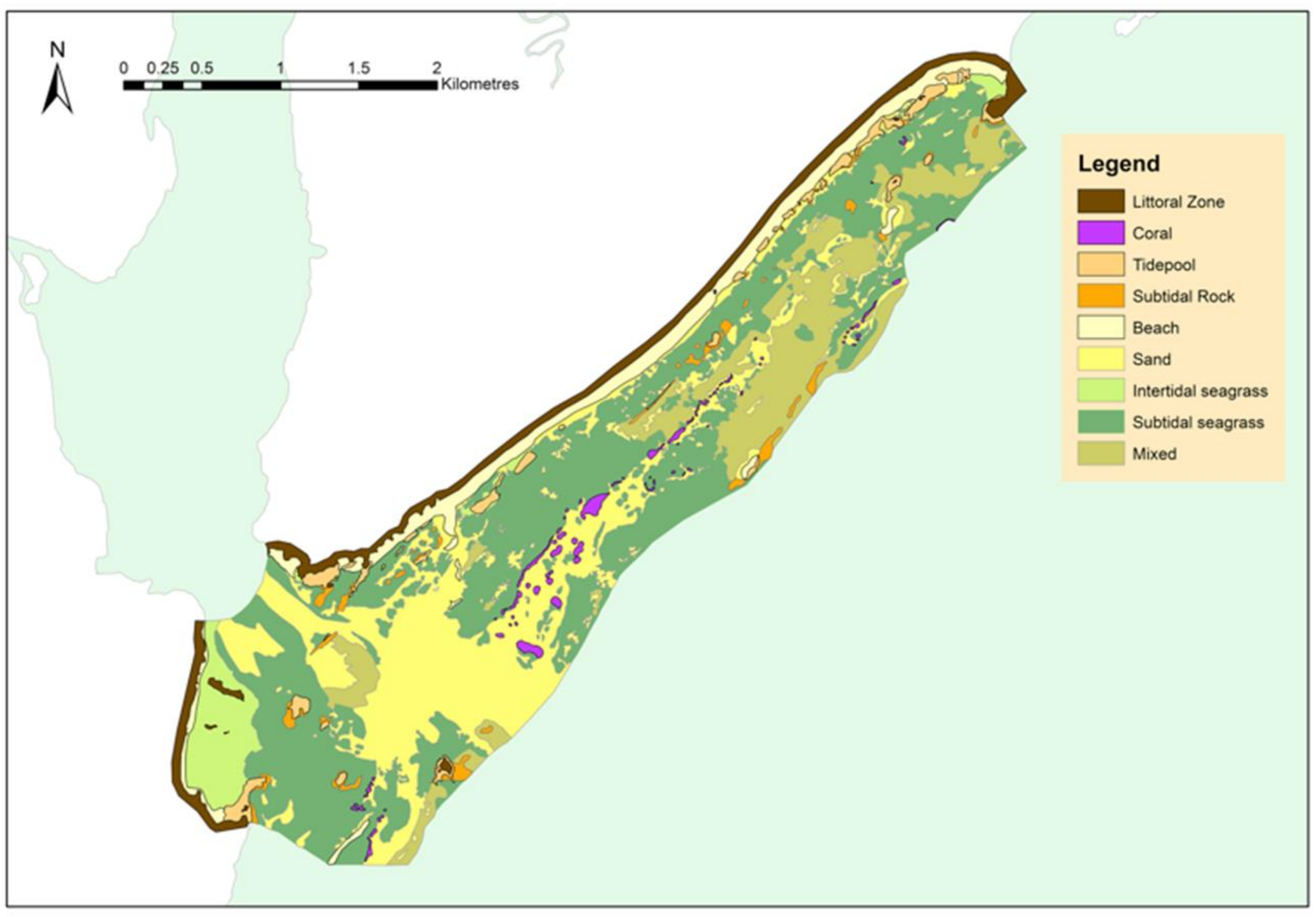

Figure 4. Map of habitats found between the reef crest and terrestrial boundary of WMNP. 


\subsection{The biodiversity of WMNP}

Table 3. Species richness of fish, echinoderms, molluscs, crustacean and seagrass, and genus richness for corals from quantitative and incidental data collection in different zones.

\begin{tabular}{|c|c|c|c|c|c|}
\hline \multirow{2}{*}{\multicolumn{2}{|c|}{ Taxon }} & \multicolumn{3}{|l|}{ Zone } & \multirow{2}{*}{$\begin{array}{l}\text { Total } \\
\text { Richness }\end{array}$} \\
\hline & & Reef & Intertidal & Subtidal & \\
\hline \multirow[t]{2}{*}{ Fish } & Quantitative & 146 & 38 & 71 & \multirow[t]{2}{*}{407} \\
\hline & Incidental & 266 & 89 & 157 & \\
\hline \multirow[t]{2}{*}{ Echinoderms } & Quantitative & 13 & 11 & n.d. & \multirow[t]{2}{*}{34} \\
\hline & Incidental & 22 & 23 & 9 & \\
\hline \multirow[t]{2}{*}{ Molluscs } & Quantitative & 17 & 32 & n.d. & \multirow[t]{2}{*}{60} \\
\hline & Incidental & 26 & 39 & 8 & \\
\hline Crustacea & Incidental & 10 & 15 & 1 & 23 \\
\hline Seagrass & Incidental & n.d. & n.d. & 11 & 11 \\
\hline Coral (genus) & Incidental & 41 & 13 & n.d. & 43 \\
\hline
\end{tabular}

Fish were the richest taxon in the park with 407 species observed from 62 families and 178 genera overall. The most speciose family were the wrasses (Labridae) with 45 species, followed by damselfish (Pomacentridae -36 species) and groupers (Serranidae - 24 species). Ten of the fish species were elasmobranchs, six of which are considered threatened (Appendix 2). Most fish had a range extending beyond the Indian Ocean with $323(81 \%)$ being Indo-Pacific, six species $(2 \%)$ with a circumtropical range, with 44 species (11\%) endemic to the WIO region. Coral reefs had the highest richness for fish observed of all the habitats (Table 3). Most coral genera were also found on the reef, but 13 genera were observed in the rocky intertidal (tidepool) zone, with 2 of these (Anomastrea and Alveopora) only seen in this habitat. Molluscs were the most speciose invertebrate taxon assessed, with incidental records of 60 species. A total of 55 mollusc species were gastropods, including 12 nudibranchs. The 34 echinoderms were comprised of nine starfish (Asteroidea), ten urchins (Echinoidea), ten sea cucumbers (Holothuroidea) and five brittlestars (Ophiuroidea). The 43 genera of corals observed came from 11 families.

There were 18 species found which have an IUCN Red List status other than least concern (LC) or data deficient (DD), with five near threatened (NT) species, 11 vulnerable (VU) species and two endangered (EN) species. Six of these species were elasmobranchs, six were bony fish (Teleosts), four sea cucumbers (Holothuroidea), one seagrass and one coral species. During species identification of fish seven potentially undescribed sweepers were observed (Pempheris spp., J. Randall, Bishop Museum, pers. comm.).

Black-tip reef shark - Carcharhinus melanopterus (NT)

White-tip reef shark - Triaenodon obesus (NT)

Blue-spotted stingray - Taeniura lymma (NT)

Brown-marbled grouper - Epinephelus fuscoguttatus (NT)

Malabar grouper - Epinephelus malabaricus (NT)

Sharp-nose stingray - Himantura gerrardi (VU)

Honeycomb stingray - Himantura uarnak (VU)

Alfred's manta ray - Manta alfredi (VU)

Giant grouper - Epinephelus lanceolatus (VU)

Saddle-back coral grouper - Plectropomus laevis (VU)

Thorny seahorse - Hippocampus hystrix (VU)

Hedgehog sea cucumber - Actinopyga echinites (VU)

10 
White-belly sea cucumber - Actinopyga mauritiana (VU)

Military sea cucumber - Actinopyga miliaris (VU)

South African eelgrass - Zostera capensis (VU)

Crisp pillow coral - Anomastraea irregularis (VU)

Humphead wrasse - Cheilinus undulatus (EN)

Edible sea cucumber - Holothuria scabra (EN)

\subsection{Completeness of biodiversity records}

Table 4. Sampling effort of quantitative data collection by taxon and habitat

\begin{tabular}{|l|l|l|l|l|}
\hline Taxon & Habitat & $\begin{array}{l}\text { Area surveyed } \\
\mathbf{( m}^{\mathbf{2}} \mathbf{n}\end{array}$ & $\begin{array}{l}\text { \% Area of } \\
\text { mapped habitats }\end{array}$ & $\begin{array}{l}\text { Number of } \\
\text { individuals } \\
\text { recorded }\end{array}$ \\
\hline \multirow{3}{*}{ Fish } & Coral reef & 4000 & $4.7 \%$ & 2409 \\
\cline { 2 - 5 } & Intertidal & 131 & $0.1 \%$ & 220 \\
\cline { 2 - 5 } & Subtidal & 14,500 & $0.2 \%$ & 1400 \\
\hline \multirow{2}{*}{ Echinoderms } & Coral reef & 800 & $0.9 \%$ & 565 \\
\cline { 2 - 5 } & Intertidal & 153 & $0.1 \%$ & 772 \\
\hline \multirow{2}{*}{ Molluscs } & Coral reef & 1440 & $1.7 \%$ & 95 \\
\cline { 2 - 5 } & Intertidal & 1510 & $0.7 \%$ & 622 \\
\hline
\end{tabular}

The area surveyed and number of individuals recorded is presented to demonstrate the sampling effort for each taxon (Table 4). The largest area covered in quantitative surveys was for fish in the subtidal zone covering $14,500 \mathrm{~m}^{2}$ (Table 4). However, as a percentage of this habitat's total area this only represents sampling of $0.2 \%$. By contrast, the smaller area covered for fish on coral reef of $4000 \mathrm{~m}^{2}$ was technically a greater sampling effort as this accounted for $4.7 \%$ of its area. Intertidal fish had the lowest sampling effort with just 220 individuals recorded from $0.1 \%$ of the total habitat in WMNP (Table 4). Species rarefaction and richness estimate curves for reef fish and subtidal fish (Figure 5a, Table 5) suggest these habitats were adequately sampled for fish, whereas intertidal fish appeared to have been under sampled. Sampling for echinoderm species lists appeared to be largely complete with the rarefaction curves for both intertidal and reef species nearing the asymptote (Figure $5 \mathrm{~b}$ ). Intertidal molluscs appeared well sampled (Figure $5 \mathrm{c}$ ), but the small number of reef molluscs observed (95) means this group is probably under sampled. It is interesting to note that in all habitats the incidental richness of fish and echinoderms (Table 3) was higher than most of the richness estimates (Table 5).

Table 5. Observed species richness and total richness estimates from quanitative data. Estimates using Jackknife1 (JK1), Jackknife2 (JK2), Chao (CH) and Bootstrap (BS).

\begin{tabular}{|l|l|l|l|l|l|l|}
\hline Taxon & Habitat & $\begin{array}{l}\text { Observed } \\
\text { Quantitative } \\
\text { Richness }\end{array}$ & JK1 & JK2 & CH & BS \\
\hline \multirow{3}{*}{ Fish } & Reef & 146 & 183 & 197 & 175 & 164 \\
\cline { 2 - 7 } & Intertidal & 38 & 58 & 76 & 137 & 46 \\
\cline { 2 - 7 } & Subtidal & 71 & 99 & 116 & 108 & 83 \\
\hline \multirow{2}{*}{ Echinoderms } & Reef & 13 & 15 & 12 & 13 & 14 \\
\cline { 2 - 7 } & Intertidal & 11 & 15 & 19 & 17 & 13 \\
\hline \multirow{2}{*}{ Molluscs } & Reef & 17 & 24 & 26 & 22 & 20 \\
\cline { 2 - 7 } & Intertidal & 32 & 42 & 42 & 37 & 37 \\
\hline
\end{tabular}



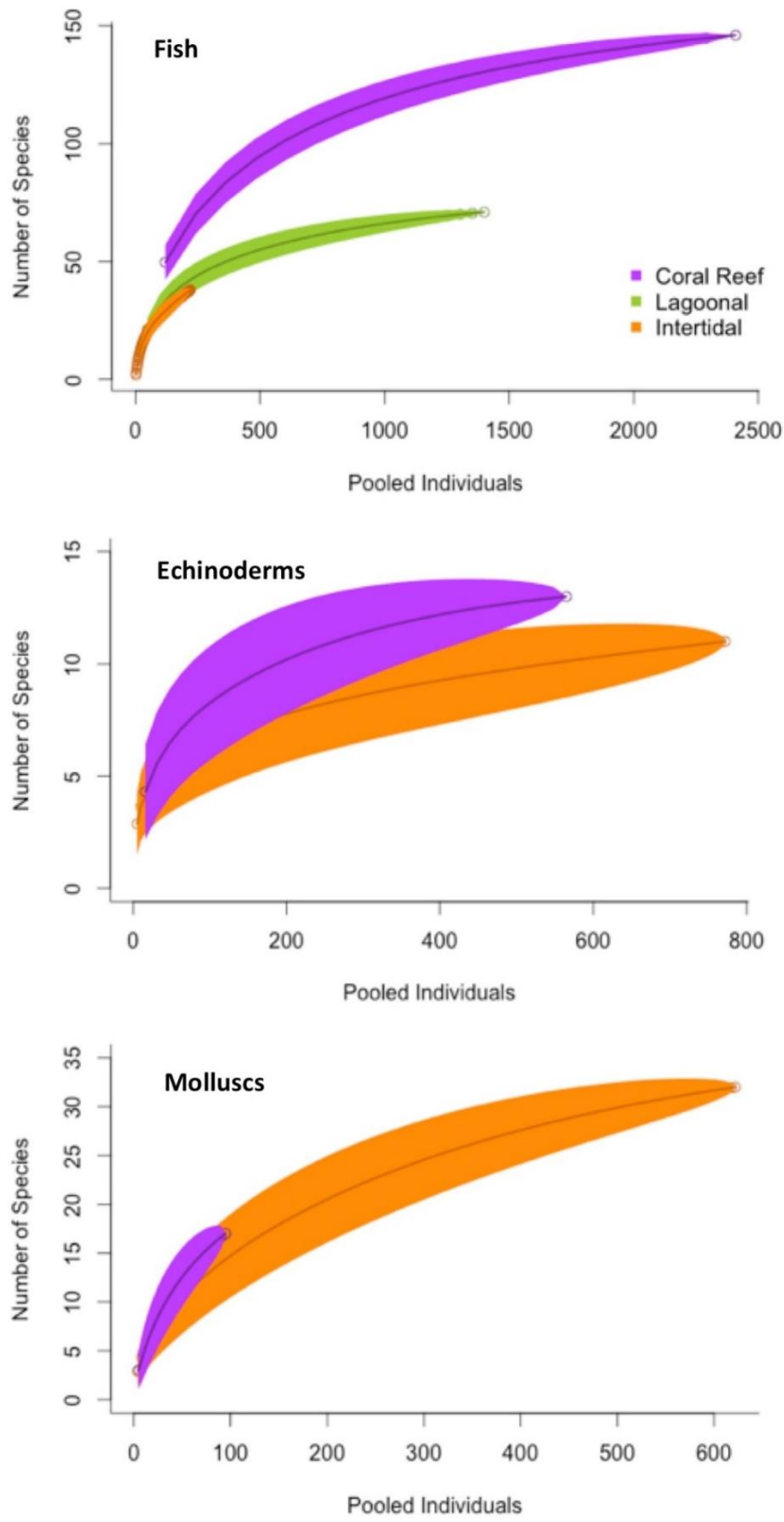

Figure 5. Rarefaction curves of species richness based on individual sampling by zones 


\section{DISCUSSION}

\subsection{Historical biodiversity records from WMNP}

During the past 50 years there have been several key studies documenting the biodiversity found in the park, all of which were published over 20 years ago. Isaac and Isaac's (1968) monograph on the ecology and biodiversity of mangroves, seagrass and seaweeds found in Kenya unfortunately doesn't present data by site, i.e., there is no information specific to Watamu. In this survey, 11 of the 12 seagrass species listed in Kenya were recorded in the park (Table 3, Appendix 2). The Bangor Expedition in 1969 collected a great deal of information on the noncoral invertebrate fauna of the park, published over the following 12 years (Appendix 1: Research Group = 'Bangor Expedition'). Humphreys (1981) lists 107 species of Echinodermata in the park, organised by habitat, niche, and relative abundance, and includes all of the 34 species recorded in this survey. The Bangor Expedition work is much more comprehensive than this survey (34 species), including infaunal (burrowing) echinoderms and more attention to the taxonomically difficult brittle stars (Ophiuroidea). The Bangor expedition also collected data on the crustaceans and polychaetes found in the park (e.g., Jones 1971, 1972, 1976 and 1982). Brander (1971) found 50 unidentfied species of polychaetes and 30 crustaceans in reef areas. A Rocha's work surveyed crustaceans incidentally and polychaetes not at all, thus these groups remain poorly known.

In 1982 Nijmegen University compiled a species list of corals (Scleractinia) found in the wider Watamu-Malindi Marine Reserve, including 113 species from 45 genera (Lemmens, 1993). This list includes 7 genera not found in A Rocha's surveys (Seriatopora, Stylophora, Pachyseris, Cynarina, Diploastrea, Physogyra and Gyrosmilia). The wider range of habitats surveyed by Nijmegen University may explain why some of these genera were not included in A Rocha's list (Appendix 2), with genera such as Pachyseris and Diploastrea being present and common outside the park, in the reserve on the fore-reef slope (B. Cowburn, pers. obs.). A Rocha's surveys found 43 genera (Table 3, Appendix 2), including three coral genera not listed in Lemmens (1993) Ctenactis, Anomastrea and Symphyllia - and also 'gained' two genera because of recent changes to coral taxonomy; Isopora which was formerly included within Acropora, and Coelastrea which was previously named Goniastrea aspera. McClanahan (1990) surveyed the sea snail fauna (Prosobranchia) of Kenya and presented quantitative records of abundance. Information about the 10 most common species is presented at the site level, meaning a complete list for WMNP is not available. A fish list was compiled for the park by local enthusiast and tour guide Mr. Richard Bennett, who has recorded nearly 500 species during his $\sim 20$ years of residence in Watamu since the 1990s.

\subsection{Research gaps and future work}

The majority of the literature related to coral reef ecology and biodiversity, despite this habitat only covering $1 \%$ of the mapped area (Table 2, Figure 4). The most understudied habitats are the seagrass beds, subtidal rocky reefs, and sandy channels in the non-reef subtidal zone, which cover $82 \%$ of the mapped park area. A heavy focus on coral reefs is not unusual in tropical marine ecology because of their considerable importance in terms of biodiversity (Plaisance et al. 2011), ecosystems services (Constanza et al. 1997) and aesthetic appeal. However, key ecological processes and biodiversity are found within other tropical marine habitats. This study found the intertidal zone had the most biodiverse echinoderm and mollusc communities (Figure 6) and recorded 10 of the 18 IUCN red-listed species of conservation concern in non-reef habitats. Sindorf et al. (2015) noted that rocky intertidal areas ( $2 \%$ of WMNP) contained a high proportion juvenile reef fish species, which are presumably using the pools as nursery grounds. The extensive seagrass beds in WMNP provide various ecological roles and ecosystem services, such as carbon storage, feeding grounds for coral reef organisms, and helping to prevent erosion 
(Gullström et al. 2002, Green and Short 2003). However, based on the current literature available for WMNP there is little known about the biodiversity or ecosystem functioning locally.

The sampling completeness for many taxa and habitats appeared complete based on quantitative results, but incidental observations recorded higher richness values than the richness estimations. This may be because there is greater habitat diversity within zones than captured from the areas covered in quantitative surveys, meaning some species ranges were not included. Species records were limited to well-documented and conspicuous groups that could be easily identified in the field. Identification of other taxa, such as soft corals (Octocorallia) and sponges (Porifera), which require a higher degree of taxonomic specialisation and the collection of specimens, was not attempted. Sampling of cryptic and infaunal invertebrate taxa require taking sediment cores and dead coral rock, which was beyond the scope of the current study, but contribute greatly to biodiversity of these taxa (Plaisance et al. 2011). Many of the taxa not assessed contribute significantly to total biodiversity of shallow marine habitats (Taylor 1971, Richmond 2002) and play a crucial role in coral-reef ecology and functioning (Diaz and Rutzler 1999). Future biodiversity assessments should prioritise infaunal species of mollusc, echinoderm and crustaceans and all species of soft corals, sponges, macroalgae, polychaetes and tunicates. This study provides the most detailed and accurate information to date of habitat distribution within the lagoon. However, the area mapped only extends to the reef crest and the remaining $1.65 \mathrm{~km} 2$ within the boundaries of WMNP is un-surveyed, without any information on the species found there. An additional gap in the mapping is for the supra-littoral habitats, recognising the differences in the dunes, coastal scrub, cliffs and islands found above the tideline, which are protected as part of the MPA.

\subsection{Conservation challenges and the conservation value of WMNP}

When WMNP was initially created, there were concerns of overexploitation in the lagoon, particularly of shells for the tourist trade (Jones 1969). In the past 50 years human population has increased dramatically in Watamu ( $>500 \%)$, triggered by tourism and migration into the area (Muthiga 2009). The presence of a large human population has had several impacts, the most obvious of which is the encroachment of the dune and beach areas of the park by hotels and other developments. Another potential impact of tourist development, which has never been formally assessed, is the increase in polluting substances entering the lagoon. Large numbers of pleasure vessels and tourist boats are moored in the northern part of the park, which could be releasing hydrocarbons and antifouling paint into the water. Inadequate sewage systems in the growing residential areas of Watamu may mean elevated levels of nutrients are entering the park. These pollutants have damaging impacts on coral and seagrass communities (Fabricius 2005, Green and Short 2003), and should be assessed and managed if necessary.

Increasing human populations on the Kenyan coast has also impacted reef fisheries, with a significant reduction in fish yields over the past 20 years (Kaunda-Arara et al. 2003, Samoilys et al. 2017). While WMNP has been moderately successful at enforcing its notake status (McClanahan et al. 2010), there exists a degree of poaching of fish and other natural resources from the park (B. Cowburn pers. obs.), the extent and impacts of which are unclear. The increasingly degraded areas around the park may be causing a 'spill-in' of negative environmental conditions (Eklof et al. 2009), through reduced larval supply, or reduced populations of fish that range both inside and out of the park. The most significant impact to the park to date was the mass bleaching and mortality of coral in 1998 (Muthiga 2009). This extreme mass-bleaching event that caused the loss of approximately $16 \%$ of reefs globally (Wilkinson 2008), saw 70\% mortality of corals in WMNP (McClanahan et al. 2001). Since 1998 there have been four minor bleaching events and, with further increases in ocean temperatures predicted, the future of corals in WMNP is under threat (van Hooidonk et al. 2016).

Despite these threats the park maintains high habitat and species diversity (Figure 4, Appendix 2) with 18 species with an IUCN red list designation of 'conservation concern'. 
Many more are listed as data deficient, including several of the grouper (Serranidae) and elasmobranches, demonstrating the need for more research into the conservation importance of thes habitats. WMNP has been effective at protecting a healthier fish community than surrounding areas (McClanahan 2014), and possesses important keystone species including the orange-lined triggerfish (Balistoides undulates) and red knobbed starfish (Protoeaster linckii). On unprotected reefs in Kenya the loss of these species through overfishing has been associated with the rapid increase of sea urchin populations Diadema spp. and Tripneustes gratillia, which has resulted in urchin overgrazing on reefs and seagrass meadows respectively (McClanahan 2000, Eklof et al. 2009). In addition to the conservation value of the park for habitats and species, protecting WMNP is also important for the local tourist economy, which attracts approximately 25,000 visitors per year, generating $€ 200,000$ per year in park entrance fees (Cowburn et al. 2013). (Appendix 2). Despite being a small MPA in a less economically developed tropical nation, WMNP is far from being a 'paper-park' and contributes to local and regional conservation efforts. It is one of the oldest MPAs in the world and has a remarkable amount of historical data collection for a Western Indian Ocean site. However, with increasing pressure from human development and climate change, the future of its habitats and biodiversity relies on effective management of threats and maintaining public support for its existence.

\section{REFERENCES}

Bennun, L. \& Njoroge, P. 2000. Important Bird Areas in Kenya. Ostrich, Journal of African Ornithology 71 (1\& 2) 164-167.

Blom, J., Van der Hagen, H., van Hove, E., Van Katwijk, M. M., Van Loon, R., \& Meier, R. (1985). Decline of the Malindi-Watamu Reef complex. Catholic University, Njimegen, The Netherlands. Pp.1-162.

Brander, K. M., McLeod, A., \& Humphreys, W. F. (1971). Comparison of species diversity and ecology of reef-living invertebrates on Aldabra Atoll and at Watamu, Kenya. Symp Zool Soc London, 28, 397-431.

Costanza, R., d'Arge, R., de Groot, R., Farber, S., Grasso, M., Hannon, B., et al. (1997). The value of the world's ecosystem services and natural capital. Nature, 387, 253-259.

Cowburn, B., Sluka, R., Smith, J., \& Mohamed, M. O. S. (2013). Tourism, Reef Health, and Visitor Enjoyment in Watamu Marine National Park, Kenya. Western Indian Ocean Journal of Marine Science, 12(1), 57-70.

Diaz, M. C., \& Rützler, K. (2001). Sponges: an essential component of Caribbean coral reefs. Bulletin of Marine Science, 12, 535-546.

Eklöf, J. S., Fröcklin, S., \& Lindvall, A. (2009). How effective are MPAs? Predation control and "spill-in effects" in seagrass-coral reef lagoons under contrasting fishery management. Marine Ecology Progress Series, 384, 83-96.

ESRI (2011). ArcGIS Desktop: Release 10. Environmental systems research institute, Redlands, USA.

ESRI (2017). http://support.esri.com/knowledge-base Environmental systems research institute, Redlands, USA. (search: 'heads up digitizing')

Fabricius, K. E. (2005). Effects of terrestrial runoff on the ecology of corals and coral reefs: review and synthesis. Marine Pollution Bulletin, 50(2), 125-146.

Ferreira, M. A. (2012). Use of satellite remote sensing for coastal conservation in the Eastern African Coast: advantages and shortcomings. European Journal of Remote Sensing, 45, 293304.

Fox, H. E., Holtzman, J. L., Haisfield, K. M., McNally, C. G., Cid, G. A., Mascia, M. B., et al. (2014). How Are Our MPAs Doing? Challenges in Assessing Global Patterns in Marine Protected Area Performance. Coastal Management, 42(3), 207-226.

Froese, R. \& Pauly, D. (2015). FishBase. www.fishbase.org 
Gotelli, N. J., \& Colwell, R. K. (2001). Quantifying biodiversity: procedures and pitfalls in the measurement and comparison of species richness. Ecology Letters, 4, 379-391.

Gotelli, N. J., \& Ellison, A. M. (2004). A primer of ecological studies. Sinauer, Sunderland, USA. Pp. 1-478

Green, E. P., \& Short, F. T. (2003). World Atlas of Seagrasses. Prepared by the UNEP World Conservation Monitoring Centre. University of California Press, Berkeley, USA. Pp. 1-297

Gullström, M., la Torre Castro, de, M., Bandeira, S., Björk, M., Dahlberg, M., Kautsky, N., et al. (2002). Seagrass ecosystems in the Western Indian Ocean. AMBIO: a Journal of the Human Environment, 31(7-8), 588-596.

Hoegh-Guldberg, O. (2014). Coral reef sustainability through adaptation: glimmer of hope or persistent mirage? Current Opinion in Environmental Sustainability, 7, 127-133.

Humphreys, W. F. (1981). The echinoderms of Kenya's marine parks and adjacent regions. Zoologische Documentatie, 19, 1-39.

Isaac, W. E., \& Isaac, F. M. (1968). Marine botany of the Kenya coast. J East Afr Nat Hist Soc Nat Mus.

Jones, D. A. (1969). Bangor-Watamu Expedition, preliminary report (pp. 1-95). University College of North Wales, Bangor, UK.

Jones, D. A. (1971). The systematics and ecology of some sand beach isopods (Crustacea: Eurydicidae) from the coast of Kenya. Journal of Zoology, 165(2), 201-227.

Jones, D. A. (1972). Aspects of the ecology and behaviour of Ocypode ceratophthalmus (Pallas) and O. kuhlii de Haan (Crustacea: Ocypodidae). Journal of Experimental Marine Biology and Ecology, 8(1), 31-43.

Jones, D. A. (1976). Te systematics and ecology of some isopods of the genus Cirolana (Cirolanidae) from the Indian Ocean region. Journal of Zoology, 178(2), 209-222.

Jones, D. A. (1982). New isopods of the genus Lanocira (Corallanidae) from the Indian Ocean Region. Crustaceana, 42(1), 65-75.

Juffe-Bignoli, D., Burgess, N. D., Bingham, H., Belle, E. M. S., de Lima, M. G., Deguignet, M., et al. (2014). Protected Planet Report 2014. UNEP World Conservation Monitoring Centre (UNEP-WCMC), Cambridge, UK. Pp. 1-67

Kaunda-Arara, B., \& Rose, G. A. (2004). Long-distance movements of coral reef fishes. Coral Reefs, 23, 410-412.

Kindt, R., \& Coe, R. (2005). Tree diversity analysis. A manual and software for common statistical methods for ecological and biodiversity studies. Nairobi World Agroforestry Centre ICRAF, 1-207.

Knowlton, N., \& Jackson, J. B. C. (2008). Shifting baselines, local impacts, and global change on coral reefs. PLoS Biology, 6(2), e54.

Lemmens, J. (1993). Reef-building corals (Cnidaria: Scleractinia) from the Watamu marine national reserve, Kenya: an annotated species list. Zoologische Mededelingen Leiden 67(32), 453-465.

Lester, S. E., Halpern, B. S., Grorud-Colvert, K., Lubchenco, J., Ruttenberg, B. I., Gaines, S. D., et al. (2009). Biological effects within no-take marine reserves: a global synthesis. Marine Ecology Progress Series, 384, 33-46.

Maynard, J. A., Anthony, K. R. N., Afatta, S., Dahl-Tacconi, N., \& Hoegh-Guldberg, O. (2010). Making a Model Meaningful to Coral Reef Managers in a Developing Nation: a Case Study of Overfishing and Rock Anchoring in Indonesia. Conservation Biology, 24(5), 1316-1326.

McClanahan, T. R. (1988). Seasonality in East Africas Coastal Waters. Marine Ecology Progress Series, 44(2), 191-199.

McClanahan, T. R. (1990). Kenyan coral reef-associated gastropod assemblages: distribution and diversity patterns. Coral Reefs, 9(2), 63-74.

McClanahan, T. R. (2000). Recovery of a coral reef keystone predator, Balistapus undulatus, in East African marine parks. Biological Conservation, 94(2), 191-198.

McClanahan, T. R. (2014). Decadal coral community reassembly on an African fringing reef. 
Coral Reefs, 33(4), 939-950.

McClanahan, T. R., Ateweberhan, M., \& Graham, N. (2007). Western Indian Ocean coral communities: bleaching responses and susceptibility to extinction. Marine Ecology Progress Series, 337, 1-13.

McClanahan, T. R., Kaunda-Arara, B., \& Omukoto, J. O. (2010). Composition and diversity of fish and fish catches in closures and open-access fisheries of Kenya. Fisheries Management and Ecology, 17(1), 63-76.

McClanahan, T., Muthiga, N., \& Mangi, S. (2001). Coral and algal changes after the 1998 coral bleaching: interaction with reef management and herbivores on Kenyan reefs. Coral Reefs, $19,380-391$.

Mora, C. (2006). ECOLOGY: Enhanced: Coral Reefs and the Global Network of Marine Protected Areas. Science (New York, N.Y.), 312(5781), 1750-1751.

Muthiga, N. A. (2009). Evaluating the effectiveness of management of the Malindi-Watamu marine protected area complex in Kenya. Ocean and Coastal Management, 52(8), 417-423.

Muthiga, N. A., \& Kawaka, J. (2010). Progress towards conservation science for Marine Protected Areas in Kenya: An annotated bibliograph. Western Indian Ocean Marine Science Association (WIOMSA), Zanzibar. Pp. 1-132

Nordlund, L. M. (2012). People and the intertidal: Human induced changes, biodiversity loss, livelihood implications and management in the Western Indian Ocean Thesis, Abo Akademi University, Abo, Finland. Pp. 1-70.

Obura, D. (2012). The Diversity and Biogeography of Western Indian Ocean Reef-Building Corals. PLoS ONE, 7(9), e45013.

Plaisance, L., Caley, M. J., Brainard, R. E., \& Knowlton, N. (2011). The diversity of coral reefs: what are we missing? PLoS ONE, 6(10), e25026.

Purkis, S. J., Graham, N. A. J., \& Riegl, B. M. (2007). Predictability of reef fish diversity and abundance using remote sensing data in Diego Garcia (Chagos Archipelago). Coral Reefs, $27(1), 167-178$.

Richmond, M. D. (2002). A field guide to the seashores of Eastern Africa and the Western Indian Ocean islands. SIDA/Department for research cooperation, SAREC, Stockholm, Sweden, pp. $1-448$.

Rowlands, G., Purkis, S., Riegl, B., Metsamaa, L., Bruckner, A., \& Renaud, P. (2012). Satellite imaging coral reef resilience at regional scale. A case-study from Saudi Arabia. Marine Pollution Bulletin, 64(6), 1222-1237.

Sale, P. F. (2008). Management of coral reefs: Where we have gone wrong and what we can do about it. Marine Pollution Bulletin, 56(5), 805-809.

Salm, R. S., \& Clark, J. R. (2000). Marine and coastal protected areas: a guide for planners and managers. Gland, Switzerland, IUCN. Pp.1-371

Samoilys, M. A., Osuka, K., Maina, G. W., \& Obura, D. O. (2017). Artisanal fisheries on Kenya's coral reefs: Decadal trends reveal management needs. Fisheries Research, 186(Part 1), 177-191.

Selig, E. R., \& Bruno, J. F. (2010). A Global Analysis of the Effectiveness of Marine Protected Areas in Preventing Coral Loss. PLoS ONE, 5(2), e9278.

Sheppard, C. P. C. (2000). Coral reefs of the Western Indian Ocean: An overview. In: McClanahan, T. R., Sheppard, C. P. C. \& Obura, D. (eds.) Coral reefs of the Indian Ocean. Oxford University Press, Oxford, UK. 3- 38

Sindorf, V., Cowburn, B., \& Sluka, R. D. (2015). Rocky intertidal fish assemblage of the Watamu Marine National Park, Kenya (Western Indian Ocean). Environmental Biology of Fishes 98 (7), 1777-1785

Taylor, J. D. (1971). Reef associated molluscan assemblages in the Western Indian Ocean. Symp Zool Soc London, 28, 3-38.

Van Katwijk, M. M., Meier, N. F., Van Loon, R., Van Hove, E. M., Giesen, W. B. J. T., van der Velde, G., \& Hartog, den, C. (1993). Sabaki River sediment load and coral stress: correlation 
between sediments and condition of the Malindi-Watamu reefs in Kenya (Indian Ocean). Marine Biology, 117(4), 675-683.

Versleijin, N. (2001). An empty sufria. The effects of a marine national park on the livelihood strategies and income diversification of fisherman households at the Kenya coast. $\mathrm{PhD}$ thesis, Wageningen University, Netherlands. Pp. 1-365

Watson, D. M. (2006). Growth rates of sea turtles in Watamu, Kenya. Earth and E-Nvironment, 2, 29-53.

Wood, L. J., Fish, L., Laughren, J., \& Pauly, D. (2008). Assessing progress towards global marine protection targets: shortfalls in information and action. Oryx, 42(03). 


\section{APPENDIX 1: \\ ANNOTATED LIST OF REFERENCES CONTAINING INFORMATION FROM \\ WATAMU MARINE NATIONAL PARK}

Alati, V M (2011). Estimating the value of goods and services in a marine protected area, the case of Watamu Marine National Park and Reserve, Kenya. Vrije Universiteit Brussel

Type: Master's thesis

Keywords: MPA, Ecosystem services

Research Group: Other

Blom, J., Van der Hagen, H., \& van Hove, E. (1985). Decline of the Malindi-Watamu Reef complex: quantitative and qualitative survey of the coral growth. Kenya-Belgium project in marine ecology.

Type: Report

Keywords: Coral, sedimentation, resilience

Research Group: 1982 University of Njimegen expedition

Brander, K. M., McLeod, A., \& Humphreys, W. F. (1971). Comparison of species diversity and ecology of reef-living invertebrates on Aldabra Atoll and at Watamu, Kenya. Symp Zool Soc London 28, 397-431

Type: Published article

Keywords: Biodiversity, invertebrates, polychaetes, crustaceans, echinoderms

Research Group: 1969 University of Bangor expedition

Bush, E. R. 2013. What's the catch? Mosquito net fishing in coastal East African. Imperial College London.

Type: Master's thesis

Keywords: Fisheries, livelihoods, health

Research Group: A Rocha

Cahill, R (1992). Birds of Watamu. Majestic printing works, Nairobi.

Type: Book

Keywords: Biodiversity, birds

Research Group: Other

Calnan, JM (2006). Changes in benthic communities in Kenyan marine protected areas. Columbia University, USA.

Type: Master's thesis

Keywords: Resilience, post-bleaching, fish, algae, MPA

Research Group: Wildlife Conservation Society

Carreiro-Silva, M. (1999). Echinoid bioerosion and herbivory on Kenyan coral reefs: the role of Marine Protected Areas. University of Wales

Type: Master's thesis (published in Carreiro-Silva and McClanahan (2001))

Keywords: Resilience, bioerosion urchins, coral, MPA

Research Group: Wildlife Conservation Society

Carreiro-Silva, M., \& McClanahan, T. R. (2001). Echinoid bioerosion and herbivory on

Kenyan coral reefs: the role of protection from fishing. Journal of Experimental Marine

Biology and Ecology, 262(2), 133-153.

Type: Published article

Keywords: Resilience, bioerosion urchins, coral, MPA 
Research Group: Wildlife Conservation Society

Cowburn, B., Sluka, R. (2012). Impact of snorkeling tourism on marine habitats of Watamu

Marine National Park. A Rocha Kenya occasional research report \#26.

Type: Report (Published in Cowburn et al. 2013)

Keywords: Tourism, MPA

Research Group: A Rocha

Cowburn, B., Sluka, R., Smith, J., \& Mohamed, M. O. S. (2013). Tourism, Reef Health, and

Visitor Enjoyment in Watamu Marine National Park, Kenya. Western Indian Ocean

Journal of Marine Science, 12(1), 57-70.

Type: Published article

Keywords: Tourism, MPA

Research Group: A Rocha

Cowburn, B., Sluka, R., Smith, J. (2013). Coral reef ecology and biodiversity in Watamu

Marine National Park, Kenya. A Rocha Kenya occasional research report \#27.

Type: Report

Keywords: Biodiversity

Research Group: A Rocha

Darling, E. S., McClanahan, T. R., \& Côté, I. M. (2010). Combined effects of two stressors on

Kenyan coral reefs are additive or antagonistic, not synergistic. Conservation Letters,

$3(2), 122-130$.

Type: Published article

Keywords: Resilience, post-bleaching, fisheries, MPA

Research Group: Wildlife Conservation Society

Darling, E. S., McClanahan, T. R., \& Côté, I. M. (2013). Life histories predict coral

community disassembly under multiple stressors. Global Change Biology 19, 1930-1940

Type: Published article

Keywords: Post-bleaching, reef ecology, coral

Davies, J. G. (2002). The attitudes of fishermen and management staff towards three marine protected areas. University of Newcastle, UK.

Type: Master's thesis (Published in McClanahan et al. 2005)

Keywords: Fisheries, MPA

Research Group: Wildlife Conservation Society

Eklöf, J. S., Fröcklin, S., \& Lindvall, A. (2009). How effective are MPAs? Predation control and "spill-in effects" in seagrass-coral reef lagoons under contrasting fishery management. Marine Ecology Progress Series, 384, 83-96

Type: Published article

Keywords: MPA, urchins

Research Group: Wildlife Conservation Society

Giesen, W., Kerkhof, K. (1984). The impact of river discharge on a Kenyan coral reef ecosystem - the physical processes. Kenya-Belgium project in marine ecology.

Type: Report

Keywords: Coral, sedimentation, resilience

Research Group: 1982 University of Njimegen expedition 
Glaesen, H. (1997). Fishers, parks and power: The socio-environmental dimensions of marine resource decline and protection on the Kenyan coast. University of WinsconsinMadison, USA

Type: $\mathrm{PhD}$ thesis

Keywords: Fisheries, livelihoods, MPAs

Research Group: Wildlife Conservation Society

Gordon, T. (2015). Defended territories of an aggressive damselfish contain lower juvenile coral density than adjacent non-defended areas on Kenyan lagoon patch reefs. University of Cambridge, UK.

Type: Undergraduate thesis (Published in Gordon et al. 2015)

Keywords: Resilience, coral recruitment, damselfish

Research Group: A Rocha

Gordon, T., Cowburn, B., \& Sluka, R. D. (2015). Defended territories of an aggressive damselfish contain lower juvenile coral density than adjacent non-defended areas on Kenyan lagoon patch reefs. Coral Reefs, 32, 13-16.

Type: Published article

Keywords: Resilience, coral recruitment, damselfish

Research Group: A Rocha

Hemery, G., \& McClanahan, T. (2005). Effect of recreational fish feeding on reef fish community composition and behaviour. Western Indian Ocean Journal of Marine Science, 4(2), 123-133.

Type: Published article

Keywords: Tourism, fish

Research Group: Wildlife conservation society

Hendrick, J. V. (1997). A survey of fish populations and feeding patterns in a Kenyan coral reef: Short-term impact of macroalgal removal and its potential in reef rehabilitation. University of Newcastle, UK.

Type: Master's thesis (Published in McClanahan et al. 1999 and McClanahan et al. 2002)

Keywords: Resilience, macroalgae, coral, fish

Research Group: Wildlife conservation society

Hereward, H., Sluka, B. (2014). Testing ghost crab density as a useful indicator of human impacts on exposed sandy beaches. A Rocha Kenya occasional research report \#29.

Type: Report

Keywords: Crab, beach ecology

Research Group: A Rocha

Holdich, D. M., \& Jones, D. A. (1973). The systematics and ecology of a new genus of sand beach isopod (Sphaeromatidae) from Kenya. Journal of the Zoological Society London, 171, 385-395.

Type: Published article

Keywords: Biodiversity, isopods

Research Group: 1969 University of Bangor expedition

Humphreys, W. F. (1981). The echinoderms of Kenya's marine parks and adjacent regions. Musee royal de l'Afrique Centrale.

Type: Book

Keywords: Biodiversity, echinoderms 
Research Group: 1969 University of Bangor expedition

Icely, J. D., \& Jones, D. A. (1978). Factors affecting the distribution of the genus Uca (Crustacea: Ocypodidae) on an East African shore. Estuarine and Coastal Marine Science, 6(3), 315-325.

Type: Published article

Keywords: Crab, beach ecology

Research Group: 1969 University of Bangor expedition

Isaac, E. W., \& Issac, F. M. (1968). Marine Botany of the Kenya Coast Journal of East Africa Natural History Society and National Museum 27(116), 7-27.

Type: Published article

Keywords: Biodiversity, algae, seagrass

Research Group: Other

Jones, D. A. (1969). Bangor-Watamu Expedition: Preliminary report. University of Bangor, $U K$

Type: Report

Keywords: Biodiversity, habitat maps, reef ecology

Research Group: 1969 University of Bangor expedition

Jones, D. A. (1971). The systematics and ecology of some sand beach isopods (Crustacea:

Eurydicidae) from the coast of Kenya. Journal of Zoology, 165(2), 201-227.

Type: Published article

Keywords: Biodiversity, ecology, isopods

Research Group: 1969 University of Bangor expedition

Jones, D. A. (1972). Aspects of the ecology and behaviour of Ocypode ceratophthalmus

(Pallas) and O. kuhlii de Haan (Crustacea: Ocypodidae). Journal of Experimental Marine Biology and Ecology, 8(1), 31-43.

Type: Published article

Keywords: Ecology, crabs

Research Group: 1969 University of Bangor expedition

Jones, D. A. (1976). The systematics and ecology of some isopods of the genus Cirolana

(Cirolanidae) from the Indian Ocean region. Journal of Zoology, 178(2), 209-222.

Type: Published article

Keywords: Biodiversity, isopods

Research Group: 1969 University of Bangor expedition

Jones, D. A. (1982). New isopods of the genus Lanocira (Corallanidae) from the Indian Ocean Region. Crustaceana, 42(1), 65-75.

Type: Published article

Keywords: Biodiversity, isopods

Research Group: 1969 University of Bangor expedition

Kamermans, P., Marten, A. H., Jurgen, F. T., Miguel, A. M., Marba, N., Mtolera, M., Stapel, J., Anouk, K., Toon, V. D. (2002). Groundwater effects on diversity and abundance of lagoonal seagrasses in Kenya and on Zanzibar Island (East Africa). Marine Ecology Progress Series 231, 75-83

Type: Published article

Keywords: 
Research Group: Kenya Marine and Fisheries Research Institute (KMFRI)

Kaunda-Arara, B. (2003). The influence of marine reserves on biodiversity conservation and adjacent fisheries in coastal Kenya. Moi University, Kenya.

Type: PhD thesis (Published in Kaunda-Arara et al. 2003 and Kaunda-Arara and Rose 2004)

Keywords: Fish, fisheries, MPA

Research Group: Other

Kaunda-Arara, B., Rose, G. A., Muchiri, M. S., \& Kaka, R. (2003). Long-term trends in coral reef fish yields and exploitation rates of commercial species from coastal Kenya.

Western Indian Ocean Journal of Marine Science 2(2), 105-116

Type: Published article

Keywords: Fish, fisheries

Research Group: Other

Kaunda-Arara, B., \& Rose, G. A. (2004). Effects of marine reef National Parks on fishery

CPUE in coastal Kenya. Biological Conservation 118, 1-13

Type: Published article

Keywords: Fish, fisheries

Research Group: Other

Kaunda-Arara, B., \& Rose, G. A. (2004). Long-distance movements of coral reef fishes. Coral Reefs, 23, 410-412.

Type: Published article

Keywords: Fish, MPA

Research Group: Other

Kaunda-Arara, B. \& Rose, G. A. (2006). Growth and survival rates of exploited coral reef fishes in Kenyan marine parks derived from tagged and length-frequency data. Western Indian Ocean Journal of Marine Science, 5(1), 17-26

Type: Published article

Keywords: Fish, fisheries, MPA

Research Group: Other

Koemans, M. (2014). Living on the edge: The relationship between livelihood practices and national reserves resources. A Rocha Kenya Occasional Research Report \#32.

Type: Report

Keywords: Livelihood

Research Group: A Rocha

Lemmens, J. (1993). Reef-building corals (Cnidaria: Scleractinia) from the Watamu marine national reserve, Kenya: an annotated species list. Zoologische Mededelingen 67, 453465.

Type: Published article

Keywords: Biodiversity, coral

Research Group: 1982 University of Njimegen expedition

McClanahan, T. R. (1989). Kenyan coral reef-associated gastropod fauna: A comparison between protected and unprotected reefs. Marine Ecology Progress Series 53, 11-20. 
Type: Published article

Keywords: Biodiversity, gastropods, tourism

Research Group: Wildlife Conservation Society

McClanahan, T. R., \& Muthiga, N. A. (1989). Patterns of predation on a sea urchin,

Echinometra mathaei (de Blainville), on Kenyan coral reefs. Journal of Experimental

Marine Biology and Ecology, 126(1), 77-94.

Type: Published article

Keywords: Urchins, fish, MPA

Research Group: Wildlife Conservation Society

McClanahan, T. R. (1990). Kenyan coral reef-associated gastropod assemblages: distribution and diversity patterns. Coral Reefs, 9(2), 63-74.

Type: Published article

Keywords: Biodiversity, gastropods, fish

Research Group: Wildlife Conservation Society

McClanahan, T. R. (1994). Coral-eating snail Drupella cornus population increases in

Kenyan coral reef lagoons. Marine Ecology Progress Series, 115, 131-137.

Type: Published article

Keywords: Drupella, coral

Research Group: Wildlife Conservation Society

McClanahan, T. R. (1994). Kenyan coral reef lagoon fish: effects of fishing, substrate

complexity, and sea urchins. Coral Reefs, 13(4), 231-241.

Type: Published article

Keywords: Reef ecology, fish, urchins

Research Group: Wildlife Conservation Society

McClanahan, T. R., Nugues, M., \& Mwachireya, S. (1994). Fish and sea urchin herbivory and competition in Kenyan coral reef lagoons: the role of reef management. Journal of Experimental Marine Biology and Ecology, 184(2), 237-254.

Type: Published article

Keywords: Reef ecology, fish, urchins, seagrass, MPA

Research Group: Wildlife Conservation Society

McClanahan, T. R., \& Mutere, J. C. (1994). Coral and sea urchin assemblage structure and interrelationships in Kenyan reef lagoons. Hydrobiologia, 286(2), 109-124.

Type: Published article

Keywords: Reef ecology, urchins, coral, MPA

Research Group: Wildlife Conservation Society

McClanahan, T. R. (1995). Fish predators and scavengers of the sea urchin Echinometra mathaei in Kenyan coral-reef marine parks. Environmental Biology of Fishes, 43(2), 187193.

Type: Published article

Keywords: Reef ecology, triggerfish, urchins

Research Group: Wildlife Conservation Society

McClanahan, T. (1997). Effects of Fishing and Reef Structure on East African Coral Reefs. Proceedings of the 8th International Coral Reef Symposium 2, 1533-1538. 
Type: Conference proceedings

Keywords: MPA, fish, urchins

Research Group: Wildlife Conservation Society

McClanahan, T. (1997). Recovery of Fish Populations from Heavy Fishing Does Time Heal

All. Proceedings of the 8th International Coral Reef Symposium 2, 2033-2038.

Type: Conference proceedings

Keywords: MPA, fish, urchins

Research Group: Wildlife Conservation Society

McClanahan, T. R., \& Obura, D. (1997). Sedimentation effects on shallow coral communities in Kenya. Journal of Experimental Marine Biology and Ecology, 209(1-2), 103-122.

Type: Published article

Keywords: Sedimentation, coral

Research Group: Wildlife Conservation Society

McClanahan, T. R. (1997). Primary succession of coral reef algae: Differing patterns on

fished versus unfished reefs. Journal of Experimental Marine Biology and Ecology, 218, 77-102

Type: Published article

Keywords: Macro-algae, fish, ecology

Research Group: Wildlife Conservation Society

McClanahan, T. R., Hendrick, V., Rodrigues, M. J., Polunin, N. V. C. (1999). Varying responses of herbivorous and invertebrate-feeding fishes to macroalgal reduction on a coral reef. Coral reefs, 18, 195-203

Type: Published article

Keywords: Macro-algae, fish, ecology

Research Group: Wildlife Conservation Society

McClanahan, T. R. (2000). Recovery of a coral reef keystone predator, Balistapus undulatus, in East African marine parks. Biological Conservation, 94(2), 191-198.

Type: Published article

Keywords: MPA, reef ecology, fish, urchins

Research Group: Wildlife Conservation Society

McClanahan, T. R., \& Arthur, R. (2001). The effect of marine reserves and habitat on

populations of East African coral reef fishes. Ecological Applications, 11(2), 559-569.

Type: Published article

Keywords: MPA, reef ecology, fish, coral, urchins

Research Group: Wildlife Conservation Society

McClanahan, T. R. (2002). The effects of time, habitat, and fisheries management on Kenyan coral-reef-associated gastropods. Ecological Applications 12(5), 1485-1495.

Type: Published article

Keywords: Gastropods, tourism, MPA

Research Group: Wildlife Conservation Society

McClanahan, T., Maina, J., \& Pet-Soede, L. (2002). Effects of the 1998 coral morality event on

Kenyan coral reefs and fisheries. $A M B I O 31,543-550$.

Type: Published article

Keywords: Post-bleaching, coral, fish, urchins 
Research Group: Wildlife Conservation Society

McClanahan, T. R. (2003). Disturbance, recovery and restoration of Kenyan coral reefs. In Hoorweg, J. \& Muthiga, N. Recent advances in coastal ecology: Studies from Kenya. African centre research report 70, 21-31.

Type: Book chapter

Keywords: Reef ecology, MPA,

Research Group: Wildlife Conservation Society

McClanahan, T. R., Baird, A. H., Marshall, P. A., \& Toscano, M. A. (2004). Comparing bleaching and mortality responses of hard corals between southern Kenya and the Great Barrier Reef, Australia. Marine Pollution Bulletin, 48(3-4), 327-335.

Type: Published article

Keywords: Post-bleaching, coral

Research Group: Wildlife Conservation Society

McClanahan, T. R., McLaughlin, S. M., Davy, J. E., Wilson, W. H., Peters, E. C., Price, K. L., \& Maina, J. (2004). Observations of a new source of coral mortality along the Kenyan coast. Hydrobiologia, 530-531(1-3), 469-479.

Type: Published article

Keywords: Coral disease

Research Group: Wildlife Conservation Society

McClanahan, T. R., \& Graham, N. (2005). Recovery trajectories of coral reef fish assemblages within Kenyan marine protected areas. Marine Ecology Progress Series, 294, 241-248.

Type: Published article

Keywords: MPA, fish, reef ecology

Research Group: Wildlife Conservation Society

McClanahan, T. R., Maina, J., Starger, C. J., Herron-Perez, P., \& Dusek, E. (2005). Detriments to post-bleaching recovery of corals. Coral Reefs, 24(2), 230-246.

Type: Published article

Keywords: Post-bleaching, reef-ecology, MPA

Research Group: Wildlife Conservation Society

McClanahan, T. R. (2006) Interactions between fisheries and management and a coral bleaching disturbance on coral reef fish in Kenya. Proceedings of the $10^{\text {th }}$ International Coral Reef Symposium, 1, 688-695

Type: Conference proceedings

Keywords: Bleaching, fish

Research Group: Wildlife Conservation Society

McClanahan, T. R., Ateweberhan, M., Muhando, C. A., Maina, J., \& Mohammed, S. M. (2007). Effects of climate and seawater temperature variation on coral bleaching and mortality. Ecological Applications 17(4), 1055-1067.

Type: Published article

Keywords: Bleaching, reef-ecology

Research Group: Wildlife Conservation Society

McClanahan, T. R., Ateweberhan, M., \& Graham, N. (2007). Western Indian Ocean coral communities: bleaching responses and susceptibility to extinction. Marine Ecology Progress Series, 337, 1-13. 
Type: Published article

Keywords: Bleaching, reef-ecology

Research Group: Wildlife Conservation Society

McClanahan, T. R., Graham, N., Calnan, J. M., \& Macneil, A. M. (2007). Toward pristine

biomass: reef fish recovery in coral reef marine protected areas in Kenya. Ecological applications, 17(4), 1055-1067.

Type: Published article

Keywords: MPA, fish

Research Group: Wildlife Conservation Society

McClanahan, T. R., Ateweberhan, M., \& Omukoto, J. (2008). Long-term changes in coral colony size distributions on Kenyan reefs under different management regimes and across the 1998 bleaching event. Marine Biology 153, 755-768.

Type: Published article

Keywords: Post-bleaching, MPA, coral, reef ecology

Research Group: Wildlife Conservation Society

McClanahan, T. R. (2008). Response of the coral reef benthos and herbivory to fishery closure management and the 1998 ENSO disturbance. Oecologia, 155(1), 169-177.

Type: Published article

Keywords: Post-bleaching, MPA, fish, coral

Research group: Wildlife conservation society

McClanahan, T. R., Cinner, J. E., Graham, N. A. J., Daw, T. M., Maina, J., Wamukota, A., Brown, K., Venus, V., Polunin, N. V. C.(2009). Identifying Reefs of Hope and Hopeful Actions: Contextualizing Environmental, Ecological, and Social Parameters to Respond Effectively to Climate Change. Conservation Biology, 23(3), 662-671

Type: Published article

Keywords: Resilience, bleaching, livelihood, MPA, reef health

Research group: Wildlife conservation society

McClanahan, T. R., Graham, N., Wilson, S. K., Letourneur, Y., \& Fisher, R. (2009). Effects of fisheries closure size, age, and history of compliance on coral reef fish communities in the Western Indian Ocean. Marine Ecology Progress Series, 396, 99-109.

Type: Published article

Keywords: MPA, fish

Research group: Wildlife conservation society

McClanahan, T. R., Kaunda-Arara, B., \& Omukoto, J. O. (2010). Composition and diversity of fish and fish catches in closures and open-access fisheries of Kenya. Fisheries

Management and Ecology, 17(1), 63-76.

Type: Published article

Keywords: MPA, fish, fisheries

Research group: Wildlife conservation society and Moi University

McClanahan, T. R. (2014). Recovery of functional groups and trophic relationships in tropical fisheries closures. Marine Ecology Progress Series, 497, 13-23.

Type: Published article

Keywords: MPA, fish

Research group: Wildlife conservation society 
Montano, S., Seveso, D., Galli, P., \& Obura, D. O. (2010). Assessing coral bleaching and recovery with a colour reference card in Watamu Marine Park, Kenya. Hydrobiologia, 655(1), 99-108.

Type: Published article

Keywords: Bleaching

Research group: Other

Musembi, P., Koemans, M. \& Kamire, J. (2014). Rockpool tourism in Watamu Marine

National Park A Rocha Kenya Occasional Research Report \#33.

Type: Report

Keywords: Tourism, intertidal, gastropods

Research Group: A Rocha

Musembi, P., Cowburn, B. (2014). Diversity and abundance of coral-associated fish in Acroporid and Pocilloporid corals of Watamu Marine National Park A Rocha Kenya Occasional Research Report \#34.

Type: Report

Keywords: Reef ecology, fish

Research Group: A Rocha

Muthiga, N. A., Njue, R. (2004). Implementing ICRAN activities at the Malindi-Watamu

MPA complex demonstration site, Kenya. In: People and reefs: Successes and challenges in the management of coral reef marine proected areas. UNEP regional seas report and studies, 176, 52-57.

Type: Report

Keywords: MPA, livelihood

Research Group: Other

Muthiga, N. A. (2009). Evaluating the effectiveness of management of the Malindi-Watamu marine protected area complex in Kenya. Ocean and coastal management 52, 417-423.

Type: Published article

Keywords: MPA

Research Group: Other

Mwaluma, J. M., Kaunda-Arara, B., Rasowo, J., Osore, M. K., \& Oresland, V. (2011).

Seasonality in fish larval assemblage structure within marine reef National Parks in coastal Kenya. Environmental Biology of Fish, 90, 393-404.

Type: Published article

Keywords: MPA, fish

Research Group: Kenya Marine and Fisheries Research Institute (KMFRI)

Naylor, C. (2014). Investigation into echinoderm species richness and abundance within the rockpool habitats of Watamu Marine National Park University of Southampton, UK.

Type: Undergraduate thesis

Keywords: Biodiversity, echinoderms, intertidal

Research Group: A Rocha

Obura, D. O. (1995). Environmental stress and life history strategies, a case study of corals and river sediment from Malindi, Kenya. University of Miami, USA

Type: $\mathrm{PhD}$ thesis (Published in McClanahan and Obura 1997)

Keywords: Sedimentation, coral

Research Group: Wildlife Conservation Society 
Okemwa, G. M., Nzuki, S., \& Mueni, E. M. (2004). The status and conservation of sea turtles in Kenya.Marine Turtle Newsletter 105, 1-6.

Type: Published article

Keywords: Turtles

Research Group: Kenya Marine and Fisheries Research Institute (KMFRI)

O'Leary, J. K. (2009). Effects of fishing and trophic interactions on tropical reef builders:

Coralline algae and corals. University of California Santa Cruz, USA.

Type: $\mathrm{PhD}$ thesis (Published in O'Leary et al. 2012).

Keywords: Reef ecology, CCA, coral

Research Group: Wildlife Conservation Society

O’Leary, J. K., Potts, D. C., Braga, J. C., McClanahan, T. R. (2012). Indirect consequences of fishing: Reduction of coralline algae suppresses juvenile coral abundance. Coral Reefs, 31, 547-559.

Type: Published article

Keywords: MPA, CCA, reef ecology

Research Group: Wildlife Conservation Society

Oman, R. (2013). The local ocean trust: Watamu Turtle Watch by-catch net release programme. Indian Ocean Turtle Newsletter, 17, 18-22.

Type: Published article

Keywords: Turtles

Research Group: Other

Orwa, O. P. (2007). Population aspects of sea cucumbers (Echinodermata: Holothuroidea) in protected and unprotected reefs along the southern Kenyan coast. University of Nairobi, Kenya.

Type: Master's thesis (Published in Orwa et al. 2009)

Keywords: Sea cucumber, biodiversity, ecology, MPA

Research Group: Other

Orwa, O. P. (2009). Holothurian population resource assessment: Mombasa marine national park and nearby unprotected reefs. In Hoorweg, J. \& Muthiga, N. A., Advances in coastal ecology: People processes and ecosystems in Kenya, African Studies Collection, 20, 162 176.

Type: Book chapter

Keywords: Sea cucumber, biodiversity, ecology

Research Group: Other

Samyn, Y. (2003) Shallow-water Holothuroidea (Echinodermata) from Kenya and Pemba Island, Tanzania. Coronet Books Inc.

Type: Book

Keywords: Biodiversity, sea cucumber

Research Group: Other

Samoilys, M. A. (1988). A survey of the coral reef fish communities on the Kenyan coast. WWF project 3797 , technical report.

Type: Report

Keywords: Biodiversity, fish

Research Group: Other 
Samoilys, M. A. (1988). Abundance and species richness of coral reef fish on the Kenyan Coast, the effects of protective management and fishing. Proceedings of the 6th International Coral Reef Symposium, 12, 261-266.

Type: Conference proceedings

Keywords: Fish, biodiversity, MPA

Research Group: Other

Sindorf, V., Cowburn, B., \& Sluka, R. D. (2015). Rocky intertidal fish assemblage of the Watamu Marine National Park, Kenya (Western Indian Ocean). Environmental Biology of Fishes

Type: Published article

Keywords: Biodiversity, fish, intertidal

Research Group: A Rocha

Sluka, R. D., Musembi, P., Cowburn, B., Jackson, C., Gijsbertsen, J. (2014). Marine research and conservation at A Rocha Kenya: 2010-2014. A Rocha Kenya Occasional Research Report \#36.

Type: Report

Keywords: MPA, biodiversity, reef ecology

Research Group: A Rocha

Tyrrell, S. (2014). The distribution and impact of sea urchins on coral reefs in Watamu, Kenya. University of Exter, $U K$.

Type: Undergraduate thesis

Keywords: Urchin, reef ecology

Research Group: A Rocha

Van Katwijk, M. M., Meier, N. F., Van Loon, R., Van Hove, E. M., Giesen, W. B. J. T., van der Velde, G., \& Hartog, den, C. (1993). Sabaki River sediment load and coral stress: correlation between sediments and condition of the Malindi-Watamu reefs in Kenya (Indian Ocean). Marine Biology, 117(4), 675-683.

Type: Published article

Keywords: Sedimentation, coral

Research Group: 1982 University of Njimegen expedition

Versleijin, N. (2001). An empty sufria. The effects of a marine national park on the livelihood strategies and income diversification of fisherman households at the Kenya coast. Wageningen University, Netherlands

Type: Master's thesis (Published in Versleijin and Hoorweg 2008 and Versleijin and Hoorweg 2009).

Keywords: Livelihood, fisheries, MPA

Research Group: Other

Versleijin, N., \& Hoorweg, J. (2008). From Farming to Fishing: Marine Resource Conservation and a New Generation of Fishermen. Western Indian Ocean Journal of Marine Science, 7(1), 1-14.

Type: Published article

Keywords: Livelihood, fisheries

Research Group: Other

Versleijin, N. \& Hoorweg, J. (2009). Marine conservation: The voice of the fishers. In Hoorweg, J. \& Muthiga, N. A., Advances in coastal ecology: People processes and 
ecosystems in Kenya, African Studies Collection, 20, 79-98.

Type: Book chapter

Keywords: Livelihood, fisheries, MPA

Research Group: Other

Wamukota, A. (2002). Marine fish marketing in Malindi and Kilifi districts, Kenya. Moi university, Kenya.

Type: Master's thesis (Published in Wamukota 2009)

Keywords: Livelihood, fisheries

Research Group: Other

Wamukota, A. (2009). The Structure of Marine Fish marketing in Kenya: The Case of

Malindi and Kilifi Districts. Western Indian Ocean Journal of Marine Science, 8(2), 215 224.

Type: Published article

Keywords: Livelihood, fisheries

Research Group: Other

Watson, D. M. (2006). Growth rates of sea turtles in Watamu, Kenya. Earth and E-

Nvironment, 2, 29-53.

Type: Published article

Keywords: Turtles

Research Group: Other

Watson, M., Ormond, R. F. G., Holliday, L. (1997). The role of Kenya's MPAs in artisanal fisheries management. Proceedings of the ${ }^{\text {th }}$ International Coral Reef Symposium, 19551960.

Type: Conference proceedings

Keywords: MPA, fisheries

Research group: Other

Weru, S. M., Wakaba, G. M., Macharia, D., Mwakau, B. K., Njue, R. M., Verheij, E., Koyo, A., Muthiga, N., Kavu, B. K., Litoro, M. (2001). Management plan: Malindi and Watamu marine parks and reserves Kenya Wildlife Services, Mombasa, Kenya

Type: Report

Keywords: MPA

Research group: Other 


\section{APPENDIX 2: SPECIES LISTS}

' $\mathrm{x}$ ' - Incidental record

' 34 ' - Abundance from quantitative surveys

\section{Appendix 2a: Fish}

\begin{tabular}{|c|c|c|c|c|c|c|}
\hline Family & Genus & Species & Common Name & Reef & Intertidal & Subtidal \\
\hline Acanthuridae & Acanthurus & dussemieri & Eyestripe surgeonfish & $\mathrm{x}$ & & 2 \\
\hline Acanthuridae & Acanthurus & leucosternon & Powderblue surgeonfish & 279 & & 1 \\
\hline Acanthuridae & Acanthurus & lineatus & Lined surgeonfish & & & $\mathrm{x}$ \\
\hline Acanthuridae & Acanthurus & nigricauda & Blackstreak surgeonfish & 38 & & 8 \\
\hline Acanthuridae & Acanthurus & nigrofuscus & Dusky surgeonfish & 34 & $\mathrm{x}$ & 65 \\
\hline Acanthuridae & Acanthurus & tennentii & Lieutenant surgeonfish & 8 & & $\mathrm{x}$ \\
\hline Acanthuridae & Acanthurus & triostegus & Convict surgeonfish & 2 & 2 & 28 \\
\hline Acanthuridae & Acanthurus & xanthopterus & Yellowfin surgeonfish & 10 & $\mathrm{x}$ & $\mathrm{x}$ \\
\hline Acanthuridae & Ctenochaetus & binotatus & Twospot Bristletooth & $\mathrm{x}$ & & \\
\hline Acanthuridae & Ctenochaetus & striatus & Striped Bristletooth & 253 & & \\
\hline Acanthuridae & Ctenochaetus & truncatus & Goldring Bristletooth & 18 & & \\
\hline Acanthuridae & Naso & annulatus & Whitemargin unicornfish & $\mathrm{x}$ & & \\
\hline Acanthuridae & Naso & brachycentron & Humpback unicornfish & 1 & & \\
\hline Acanthuridae & Naso & brevirostris & Spotted unicornfish & 17 & & \\
\hline Acanthuridae & Naso & elegans & Orangespine unicornfish & 7 & & \\
\hline Acanthuridae & Naso & fageni & Horse-face unicornfish & $\mathrm{x}$ & & \\
\hline Acanthuridae & Naso & unicornis & Bluespine unicornfish & 26 & & \\
\hline Acanthuridae & Naso & vlamingi & Bignose unicornfish & $\mathrm{x}$ & & \\
\hline Acanthuridae & Zebrasoma & desjardinii & Desjardin's sailfin tang & 2 & & \\
\hline Acanthuridae & Zebrasoma & scopas & Brown tang & 24 & & \\
\hline Antennariidae & Histrio & histrio & Sargassumfish & & & \\
\hline Apogonidae & Apogon & nigripes & Blackfoot cardinalfish & & & 102 \\
\hline Apogonidae & Apogon & semiornatus & Obliquebanded cardinalfish & & & \\
\hline Apogonidae & Apogonichthyoides & taeniatus & Twobelt cardinalfish & & $\mathrm{x}$ & \\
\hline Apogonidae & Archamia & fucata & Orange-lined cardinalfish & $\mathrm{x}$ & & \\
\hline Apogonidae & Cheilodipterus & arabicus & Tiger cardinalfish & $\mathrm{x}$ & & 7 \\
\hline Apogonidae & Cheilodipterus & artus & Wolf cardinalfish & $\mathrm{x}$ & & \\
\hline Apogonidae & Cheilodipterus & macrodon & Large-tooth cardinalfish & $\mathrm{x}$ & & \\
\hline Apogonidae & Cheilodipterus & quinquelineatus & Five-lined cardinalfish & $\mathrm{x}$ & $\mathrm{x}$ & \\
\hline Apogonidae & Ostorhinchus & angustatus & Broad-striped cardinalfish & $\mathrm{x}$ & & \\
\hline Apogonidae & Ostorhinchus & aureus & Ring-tailed cardinalfish & $\mathrm{x}$ & & \\
\hline Apogonidae & Ostorhinchus & cookii & Cook's cardinalfish & $\mathrm{x}$ & 17 & 6 \\
\hline Apogonidae & Ostorhinchus & cyanosoma & Yellow-striped cardinalfish & $\mathrm{x}$ & & 2 \\
\hline Apogonidae & Ostorhinchus & flagellifera & Coachwhip cardinalfish & $\mathrm{x}$ & & \\
\hline Apogonidae & Ostorhinchus & nigrofasciatus & Black-stripe cardinalfish & $\mathrm{x}$ & & \\
\hline
\end{tabular}




\begin{tabular}{|c|c|c|c|c|c|c|}
\hline Apogonidae & Ostorhinchus & taeniophorus & Reef-flat cardinalfish & & 5 & 104 \\
\hline Apogonidae & Pristapogon & kallopterus & Iridescent cardinalfish & $\mathrm{x}$ & 1 & \\
\hline Atherinidae & Atherinomorus & lacunosus & Hardy silverhead & & $\mathrm{x}$ & $\mathrm{x}$ \\
\hline Aulostomidae & Aulostomus & chinensus & Trumpetfish & 5 & & \\
\hline Balistidae & Balistoides & undulatus & Orange-strip triggerfish & 4 & & \\
\hline Balistidae & Balistoides & viridescens & Giant triggerfish & $\mathrm{x}$ & & \\
\hline Balistidae & Pseudobalistes & flavimarginatus & Yellowmargin triggerfish & & $\mathrm{x}$ & \\
\hline Balistidae & Pseudobalistes & fuscus & Blue triggerfish & $\mathrm{x}$ & & \\
\hline Balistidae & Rhinecanthus & assasi & Picassofish & 1 & $\mathrm{x}$ & 20 \\
\hline Balistidae & Rhinecanthus & rectangulus & Wedge picassofish & & $\mathrm{x}$ & 1 \\
\hline Balistidae & Sufflamen & chrysopterus & Halfmoon triggerfish & 10 & & 1 \\
\hline Balistidae & Sufflamen & fraenatus & Bridled triggerfish & 3 & & 1 \\
\hline Blenniidae & Antennablennius & variopunctatus & Orange-spot blenny & & 21 & \\
\hline Blennidae & Aspidontus & taeniatus & Cleanerfish mimic & & & \\
\hline Blenniidae & Blenniella & chrysospilos & Red-spotted blenny & & $\mathrm{x}$ & \\
\hline Blenniidae & Blenniella & cyanostigma & Striped rockskipper & & 19 & \\
\hline Blenniidae & Cirripectes & castaneus & Chestnut blenny & 3 & & \\
\hline Blenniidae & Cirripectes & stigmaticus & Redstreaked blenny & $\mathrm{x}$ & & \\
\hline Blenniidae & Entomacrodus & striatus & Blackspotted rockskipper & & $\mathrm{x}$ & \\
\hline Blenniidae & Exallias & brevis & Leopard blenny & 1 & & \\
\hline Blenniidae & Hirculops & cornifer & Highbrow rockskipper & & 1 & \\
\hline Blenniidae & Istiblennius & lineatus & Lined rockskipper & & $\mathrm{x}$ & \\
\hline Blenniidae & Istiblennius & unicolor & Pallid rockskipper & & 1 & \\
\hline Blenniidae & Meiacanthus & mossambicus & Mocambique fangblenny & 3 & & \\
\hline Blenniidae & Plagiotremus & rhinorhynchos & Bluestriped fangblenny & 1 & $\mathrm{x}$ & \\
\hline Blenniidae & Plagiotremus & tapeinosoma & Scale-eating fangblenny & 1 & & $\mathrm{x}$ \\
\hline Blenniidae & Salarias & fasciatus & Jeweled blenny & & 1 & \\
\hline Caesionidae & Caesio & caerulaurea & Scissor-tailed fusilier & $\mathrm{x}$ & & \\
\hline Caesionidae & Caesio & lunaris & Lunar fusilier & 6 & & \\
\hline Caesionidae & Caesio & teres & Yellowback fusilier & $\mathrm{x}$ & & \\
\hline Caesionidae & Caesio & xanthonota & Yellowtop fusilier & $\mathrm{x}$ & & \\
\hline Caesionidae & Dipterygonotus & balteatus & Mottled fusilier & $\mathrm{x}$ & & \\
\hline Caesionidae & Pterocaesio & chrysozona & Goldband fusilier & 30 & & \\
\hline Callionymidae & Synichiropus & stellatus & Starry dragonet & $\mathrm{x}$ & & \\
\hline Caracanthidae & Caracanthus & madagascariensis & Spotted coral croucher & $\mathrm{x}$ & & \\
\hline Caracanthidae & Caracanthus & unipinna & Pygmy coral croucher & $\mathrm{x}$ & & \\
\hline Carangidae & Alectis & inidicus & Indian threadfin & & & $\mathrm{x}$ \\
\hline Carangidae & Carangoides & ferdau & Bar jack & $\mathrm{x}$ & & \\
\hline Carangidae & Carangoides & fulvoguttatus & Yellow-dotted trevally & $\mathrm{x}$ & & \\
\hline Carangidae & Caranx & herberi & Black-tip trevally & $\mathrm{x}$ & & \\
\hline Carangidae & Caranx & ignobilis & Giant trevally & & & $\mathrm{x}$ \\
\hline Carangidae & Caranx & melampygus & Bluefin trevally & 1 & & \\
\hline
\end{tabular}




\begin{tabular}{|c|c|c|c|c|c|c|}
\hline Carangidae & Caranx & papuensis & Brassy trevally & $\mathrm{x}$ & & \\
\hline Carangidae & Caranx & sexfasciatus & Bigeye trevally & $\mathrm{x}$ & & \\
\hline Carangidae & Gnathanodon & speciosus & Golden trevally & & & $\mathrm{x}$ \\
\hline Carangidae & Scomberoides & lysan & Doublespot queenfish & $\mathrm{x}$ & & \\
\hline Carangidae & Trachinostus & blochii & Silver pompano & & & $\mathrm{x}$ \\
\hline Carcharhinidae & Carcharhinus & melanopterus & Reef blacktip shark & & & $\mathrm{x}$ \\
\hline Carcharhinidae & Triaenodon & obesus & Reef whitetip shark & $\mathrm{x}$ & & \\
\hline Centriscidae & Aeoliscus & punctulatus & Speckled shrimpfish & & & $\mathrm{x}$ \\
\hline Chaetodontidae & Chaetodon & auriga & Threadfin butterflyfish & 13 & $\mathrm{x}$ & 4 \\
\hline Chaetodontidae & Chaetodon & falcula & Saddleback butterflyfish & $\mathrm{x}$ & & \\
\hline Chaetodontidae & Chaetodon & guttatissimus & Spotted butterflyfish & 2 & & \\
\hline Chaetodontidae & Chaetodon & kleinii & Klein's butterflyfish & $\mathrm{x}$ & & 1 \\
\hline Chaetodontidae & Chaetodon & lineolatus & Lined butterflyfish & $\mathrm{x}$ & & \\
\hline Chaetodontidae & Chaetodon & leucopleura & Somali butterflyfish & & & $\mathrm{x}$ \\
\hline Chaetodontidae & Chaetodon & lunula & Raccoon butterflyfish & 14 & $\mathrm{x}$ & 5 \\
\hline Chaetodontidae & Chaetodon & meyeri & Meyer's butterflyfish & 4 & & \\
\hline Chaetodontidae & Chaetodon & trifascialis & Chevroned butterflyfish & 4 & & \\
\hline Chaetodontidae & Chaetodon & trifasciatus & Redfin butterflyfish & 7 & & \\
\hline Chaetodontidae & Chaetodon & vagabundus & Vagabond butterflyfish & & & $\mathrm{x}$ \\
\hline Chaetodontidae & Chaetodon & xanthocephalus & Yellowhead butterflyfish & 1 & & \\
\hline Chaetodontidae & Forcipiger & flavissimus & Long-nose butterflyfish & $\mathrm{x}$ & & \\
\hline Chaetodontidae & Heniochus & acuminatus & Longfin bannerfish & $\mathrm{x}$ & & \\
\hline Chaetodontidae & Heniochus & monoceros & Masked bannerfish & 2 & & \\
\hline Cirrihitidae & Amblycirrihitus & bimacula & Two-spotted hawkfish & $\mathrm{x}$ & & \\
\hline Cirrihitidae & Paracirrhites & arcatus & Monocle hawkfish & 2 & & \\
\hline Cirrihitidae & Paracirrhites & forsteri & Freckled hawkfish & 7 & & \\
\hline Cirrihitidae & Cirrhitichthys & oxycephalus & Pixy hawkfish & $\mathrm{x}$ & & \\
\hline Cirrihitidae & Cirrhitus & pinnulatus & Stocky hawkfish & & & $\mathrm{x}$ \\
\hline Clupeidae & Herklotsichthys & quadrimaculatus & Gold spot herring & & $\mathrm{x}$ & $\mathrm{x}$ \\
\hline Clupeidae & Spratelloides & gracilis & Blue lateral sprat & & & $\mathrm{x}$ \\
\hline Congridae & Conger & cinereus & Moustache conger & & & \\
\hline Dasyatidae & Himantura & gerrardi & Sharpnose stingray & & & $\mathrm{x}$ \\
\hline Dasyatidae & Himantura & uarnak & Honeycomb stingray & & & $\mathrm{x}$ \\
\hline Dasyatidae & Neotrygon & kuhlii & Bluespotted stingray (grey) & & & $\mathrm{x}$ \\
\hline Dasyatidae & Taeniura & lymma & Bluespotted Stingray & 1 & & $\mathrm{x}$ \\
\hline Diodontidae & Diodon & hystrix & Porcupinefish & $\mathrm{x}$ & $\mathrm{x}$ & 1 \\
\hline Diodontidae & Diodon & liturosus & Black-blotched porcupinefish & $\mathrm{x}$ & $\mathrm{x}$ & $\mathrm{x}$ \\
\hline Echeneidae & Echeneis & naucrates & Sharksucker & $\mathrm{x}$ & & \\
\hline Ephippidae & Platax & orbicularis & Batfish & 7 & & \\
\hline Ephippidae & Platax & teira & Longfin spadefish & & $\mathrm{x}$ & \\
\hline Ephippidae & Tripterodon & orbis & African spadefish & & & \\
\hline Fistulariidae & Fistularia & commersonii & Cornetfish & 6 & & \\
\hline
\end{tabular}




\begin{tabular}{|c|c|c|c|c|c|c|}
\hline Gerreidae & Gerres & longirostris & Smallscale mojarra & & $\mathrm{x}$ & \\
\hline Gerreidae & Gerres & oyena & Blacktip mojarra & & $\mathrm{x}$ & $\mathrm{x}$ \\
\hline Gobiidae & Amblyeleotris & wheeleri & Gorgeous prawn-goby & & & $\mathrm{x}$ \\
\hline Gobiidae & Cryptocentrus & fasciastus & Barred prawn-goby & & & $\mathrm{x}$ \\
\hline Gobiidae & Cryptocentrus & lutheri & Luther's prawn-goby & & & $\mathrm{x}$ \\
\hline Gobiidae & Cryptocentrus & strigilliceps & Target prawn-goby & & & $\mathrm{x}$ \\
\hline Gobiidae & Ctenogobiops & feroculus & Sandy prawn-goby & & & $\mathrm{x}$ \\
\hline Gobiidae & Gnatholepis & cauerensis & Eye-bar goby & & 7 & \\
\hline Gobiidae & Gnatholepis & scapulostigma & Shoulder-spot goby & & $\mathrm{x}$ & \\
\hline Gobiidae & Istigobius & ornatus & Ornate goby & & 4 & \\
\hline Gobiidae & Paragobiodon & modestus & Modest goby & $\mathrm{x}$ & & \\
\hline Gobiidae & Pleurosicya & micheli & Michels ghost goby & $\mathrm{x}$ & & \\
\hline Gobiidae & Valenciennea & strigata & Blue-streak goby & $\mathrm{x}$ & & $\mathrm{x}$ \\
\hline Haemulidae & Plectorhinchus & albovittatus & Giant sweetlips & & & $\mathrm{x}$ \\
\hline Haemulidae & Plectorhinchus & chubbi & Dusky sweetlips & $\mathrm{x}$ & & \\
\hline Haemulidae & Plectorhinchus & flavomaculatus & Gold-spotted sweetlips & 38 & & 20 \\
\hline Haemulidae & Plectorhinchus & gaterinus & Black-spotted sweetlips & 29 & & \\
\hline Haemulidae & Plectorhinchus & gibbosus & Gibbus sweetlips & & & $\mathrm{x}$ \\
\hline Haemulidae & Plectorhinchus & paulayi & Diagonal-lined sweetlips & & & $\mathrm{x}$ \\
\hline Haemulidae & Plectorhinchus & plagiodesmus & Red-lined sweetlips & & & $\mathrm{x}$ \\
\hline Haemulidae & Plectorhinchus & playfairi & Whitebarred sweetlips & 6 & & \\
\hline Haemulidae & Plectorhinchus & schotaf & Somber sweetlips & 1 & & $\mathrm{x}$ \\
\hline Haemulidae & Plectorhinchus & sordidus & Black sweetlips & & & $\mathrm{x}$ \\
\hline Haemulidae & Plectorhinchus & vittatus & Oriental sweetlips & $\mathrm{x}$ & & \\
\hline Hemiramphidae & Hyporhamphus & affinis & Insular halfbeak & & & $\mathrm{x}$ \\
\hline Hemiramphidae & Hemiramphus & far & Spotted halfbeak & & & 5 \\
\hline Holocentridae & Myripristis & adusta & Bronze soldierfish & & & \\
\hline Holocentridae & Myripristis & hexagona & Doubletoothed soldierfish & 4 & & \\
\hline Holocentridae & Myripristis & murdjan & Red soldierfish & & & $\mathrm{x}$ \\
\hline Holocentridae & Myripristis & pralinia & Scarlet soldierfish & & & $\mathrm{x}$ \\
\hline Holocentridae & Myripristis & violacea & Violet soldierfish & 3 & & \\
\hline Holocentridae & Neoniphon & argenteus & Clearfin soldierfish & & & \\
\hline Holocentridae & Neoniphon & sammara & Bloodspot soldierfish & $\mathrm{x}$ & & \\
\hline Holocentridae & Plectrypops & lima & Cardinal soldierfish & & $\mathrm{x}$ & \\
\hline Holocentridae & Sargocentron & caudimaculatum & Tailspot squirrelfish & $\mathrm{x}$ & & \\
\hline Holocentridae & Sargocentron & diadema & Crown squirrelfish & 2 & & 7 \\
\hline Kuhliidae & Kuhlia & mugil & Barred flagtail & & $\mathrm{x}$ & \\
\hline Kyphosidae & Kyphosus & cinerascens & Highfin rudderfish & $\mathrm{x}$ & & \\
\hline Kyphosidae & Kyphosus & vaigiensis & Brassy rudderfish & 65 & & \\
\hline Labridae & Anampses & caeruleopunctatus & Blue-spotted wrasse & 3 & & \\
\hline Labridae & Anampses & melanurus & White-spotted wrasse & $\mathrm{x}$ & & \\
\hline Labridae & Anampses & meleagrides & Yellowtail wrasse & 1 & & \\
\hline
\end{tabular}




\begin{tabular}{|c|c|c|c|c|c|c|}
\hline Labridae & Anampses & twistii & Yellow-breasted wrasse & 5 & & \\
\hline Labridae & Bodianus & axillaris & Axilspot hogfish & 9 & & \\
\hline Labridae & Bodianus & diana & Diana's hogfish & $\mathrm{x}$ & & \\
\hline Labridae & Cheilinus & chlorourus & Floral wrasse & $\mathrm{x}$ & & $\mathrm{x}$ \\
\hline Labridae & Cheilinus & oxycephalus & Snooty wrasse & 4 & & \\
\hline Labridae & Cheilinus & trilobatus & Tripletail wrasse & 23 & & 14 \\
\hline Labridae & Cheilio & inermis & Cigar wrasse & 2 & $\mathrm{x}$ & 27 \\
\hline Labridae & Coris & aygula & Clown Coris & 2 & & \\
\hline Labridae & Coris & caudimacula & Spottail Coris & 3 & 1 & 24 \\
\hline Labridae & Coris & cuvieri & African Coris & 1 & & 2 \\
\hline Labridae & Coris & formosa & Queen Coris & 1 & $\mathrm{x}$ & 9 \\
\hline Labridae & Epibulus & insidiator & Slingjaw wrasse & 2 & & \\
\hline Labridae & Gomphosus & caeruleus & Indian bird wrasse & 15 & & \\
\hline Labridae & Halichoeres & hortulanus & Checkerboard wrasse & 26 & 2 & 3 \\
\hline Labridae & Halichoeres & marginatus & Dusky wrasse & 6 & & \\
\hline Labridae & Halichoeres & nebulosus & Nebulous wrasse & & & 45 \\
\hline Labridae & Halichoeres & scapularis & Zigzag wrasse & 2 & 1 & 3 \\
\hline Labridae & Hemigymnus & fasciastus & Barred thicklip wrasse & 6 & & \\
\hline Labridae & Hemigymnus & melapterus & Blackedge thicklip wrasse & $\mathrm{x}$ & & \\
\hline Labridae & Hologymnosus & annulatus & Ring wrasse & 2 & & 2 \\
\hline Labridae & Iniistius & pavo & Blue razorfish & & & $\mathrm{x}$ \\
\hline Labridae & Iniistius & pentadactylus & Fivefinger razorfish & & & $\mathrm{x}$ \\
\hline Labridae & Labrichthys & unilineatus & Tubelip wrasse & 5 & & \\
\hline Labridae & Labroides & bicolor & Bicolour cleaner wrasse & 3 & & \\
\hline Labridae & Labroides & dimidiatus & Bluestreak cleaner wrasse & 32 & 6 & 17 \\
\hline Labridae & Macropharyngodon & bipartitus & Vermiculate wrasse & $\mathrm{x}$ & & 5 \\
\hline Labridae & Novaculichthys & macrolepidotus & Seagrass wrasse & & & 19 \\
\hline Labridae & Novaculichthys & taeniourus & Dragon wrasse & 2 & & \\
\hline Labridae & Oxycheilinus & bimaculatus & Twospot wrasse & $\mathrm{x}$ & & \\
\hline Labridae & Oxycheilinus & digrammus & Bandcheek wrasse & 6 & & \\
\hline Labridae & Pseudocheilinus & evanidus & Disappearing wrasse & $\mathrm{x}$ & & \\
\hline Labridae & Pseudocheilinus & hexataenia & Six-line wrasse & 17 & & \\
\hline Labridae & Pteragogus & flagellifera & Flagfin wrasse & $\mathrm{x}$ & & \\
\hline Labridae & Stethojulis & albovittata & Bluelined wrasse & $\mathrm{x}$ & $\mathrm{x}$ & 28 \\
\hline Labridae & Stethojulis & strigiventer & Three-line wrasse & $\mathrm{x}$ & $\mathrm{x}$ & \\
\hline Labridae & Thalassoma & amblycephalum & Two tone wrasse & 58 & 1 & $\mathrm{x}$ \\
\hline Labridae & Thalassoma & hardwicke & Six-bar wrasse & 19 & & 2 \\
\hline Labridae & Thalassoma & hebraicum & Goldbar wrasse & 62 & 11 & 5 \\
\hline Labridae & Thalassoma & lunare & Crescent wrasse & 5 & & 3 \\
\hline Labridae & Thalassoma & purpureum & Surge wrasse & & & $\mathrm{x}$ \\
\hline Labridae & Thalassoma & quinquevittatum & Five-stripe wrasse & & & $\mathrm{x}$ \\
\hline Labridae & Thalassoma & trilobatum & Christmas wrasse & $\mathrm{x}$ & & \\
\hline
\end{tabular}




\begin{tabular}{|c|c|c|c|c|c|c|}
\hline Lethrinidae & Gnathodentex & aurolineatus & Yellowspot emperor & $\mathrm{x}$ & & \\
\hline Lethrinidae & Lethrinus & harak & Blackspot emperor & 1 & $\mathrm{x}$ & 45 \\
\hline Lethrinidae & Lethrinus & lentjan & Pink-ear emperor & & & $\mathrm{x}$ \\
\hline Lethrinidae & Lethrinus & mehsena & Sky emperor & 7 & & $\mathrm{x}$ \\
\hline Lethrinidae & Lethrinus & microdon & Smalltooth emperor & 1 & & \\
\hline Lethrinidae & Lethrinus & obsoletus & Orange-stripe emperor & $\mathrm{x}$ & & \\
\hline Lethrinidae & Monotaxis & grandoculis & Big-eye emperor & 4 & & \\
\hline Lutjanidae & Lutjanus & argentimaculatus & River snapper & 11 & & $\mathrm{x}$ \\
\hline Lutjanidae & Lutjanus & bohar & Red snapper & 17 & & \\
\hline Lutjanidae & Lutjanus & coeruleolineatus & Blueline snapper & & & \\
\hline Lutjanidae & Lutjanus & ehrenbergi & Ehrenberg's snapper & & & $\mathrm{x}$ \\
\hline Lutjanidae & Lutjanus & fluvus & Flametail snapper & $\mathrm{x}$ & & \\
\hline Lutjanidae & Lutjanus & fulviflamma & Blackspot snapper & 42 & 1 & 2 \\
\hline Lutjanidae & Lutjanus & gibbus & Humpback snapper & 3 & & \\
\hline Lutjanidae & Lutjanus & kasmira & Blue-lined snapper & 1 & 1 & \\
\hline Lutjanidae & Lutjanus & monostigma & One-spot snapper & $\mathrm{x}$ & & \\
\hline Lutjanidae & Lutjanus & rivulatus & Scribbled snapper & $\mathrm{x}$ & & \\
\hline Lutjanidae & Macolor & niger & Black and white snapper & 4 & & \\
\hline Microdesmidae & Ptereleotris & evides & Blackfin dartfish & 50 & & \\
\hline Microdesmidae & Ptereleotris & microlepis & Pearly dartfish & & & $\mathrm{x}$ \\
\hline Mobulidae & Manta & alfredi & Alfred manta & & & $\mathrm{x}$ \\
\hline Monacanthidae & Acreichthys & tomentosus & Seagrass filefish & & & \\
\hline Monacanthidae & Aluterus & scriptus & Scribbled filefish & 1 & & \\
\hline Monacanthidae & Cantherhines & fronticinctus & Spectacled filefish & $\mathrm{x}$ & $\mathrm{x}$ & \\
\hline Monacanthidae & Cantherhines & pardalis & Wire-net filefish & 4 & & $\mathrm{x}$ \\
\hline Monacanthidae & Oxymonacanthus & longirostris & Longnose filefish & 2 & & \\
\hline Monacanthidae & Paraluteres & prionurus & Saddleback mimic & & & \\
\hline Monacanthidae & Pervagor & janthinosoma & Blackbar filefish & 2 & & \\
\hline Monodactylidae & Monodactylus & argenteus & Silver batfish & & & 10 \\
\hline Mugilidae & Oedalechilus & labiosus & Foldlip mullet & & $\mathrm{x}$ & \\
\hline Mugilidae & Valamugil & seheli & Bluespot mullet & & & $\mathrm{x}$ \\
\hline Mullidae & Mulloidichthys & flavolineatus & Yellowstripe goatfish & 2 & & \\
\hline Mullidae & Mulloidichthys & vanicolensis & Yellowfin goatfish & $\mathrm{x}$ & & \\
\hline Mullidae & Parupeneus & bifasciatus & Two-barred goatfish & & & $\mathrm{x}$ \\
\hline Mullidae & Parupeneus & barberinus & Dash and dot goatfish & 55 & $\mathrm{x}$ & 11 \\
\hline Mullidae & Parupeneus & ciliatus & Whitesaddle goatfish & $\mathrm{x}$ & & \\
\hline Mullidae & Parupeneus & cyclostomus & Yellow-saddle goatfish & 1 & & \\
\hline Mullidae & Parupeneus & indicus & Indian goatfish & 2 & & 10 \\
\hline Mullidae & Parupeneus & macronema & Longbarbel goatfish & $\mathrm{x}$ & & 2 \\
\hline Mullidae & Parupeneus & rubescens & Rosy goatfish & $\mathrm{x}$ & & $\mathrm{x}$ \\
\hline Mullidae & Upeneus & tragula & Blackstriped goatfish & & & $\mathrm{x}$ \\
\hline Muraenidae & Echidna & leucotaenia & Whiteface moray & $\mathrm{x}$ & 1 & \\
\hline
\end{tabular}




\begin{tabular}{|c|c|c|c|c|c|c|}
\hline Muraenidae & Echidna & nebulosa & Snowflake moray & $\mathrm{x}$ & 1 & \\
\hline Muraenidae & Gymnomuraena & zebra & Zebra moray & & $\mathrm{x}$ & \\
\hline Muraenidae & Gymnothorax & chilospilos & Lipspot moray & & & \\
\hline Muraenidae & Gymnothorax & favagineus & Honeycomb moray & & & $\mathrm{x}$ \\
\hline Muraenidae & Gymnothorax & flavimarginatus & Yellow-margined moray & $\mathrm{x}$ & & \\
\hline Muraenidae & Gymnothorax & grisea & Geometric moray & $\mathrm{x}$ & & \\
\hline Muraenidae & Gymnothorax & pictus & Peppered moray & & $\mathrm{x}$ & \\
\hline Muraenidae & Gymnothorax & undulatus & Undulated moray & & & \\
\hline Muraenidae & Scuticaria & tigrinus & Tiger snake moray & $\mathrm{x}$ & & \\
\hline Muraenidae & Uropterygius & marmoratus & Marbled snake moray & & & \\
\hline Myliobatidae & Aetobatus & ocellatus & Spotted eagle ray & & & $\mathrm{x}$ \\
\hline Nemipteridae & Scolopsis & ghanam & Arabian spinecheek & 2 & $\mathrm{x}$ & \\
\hline Ophichthidae & Callechelys & marmorata & Marbled snake eel & & & $\mathrm{x}$ \\
\hline Ophichthidae & Myrichthys & colubrinus & Harlequin snake eel & $\mathrm{x}$ & & \\
\hline Ophichthidae & Myrichthys & maculosus & Spotted snake eel & $\mathrm{x}$ & & \\
\hline Ostraciidae & Lactoria & cornuta & Longhorn cowfish & & $\mathrm{x}$ & \\
\hline Ostraciidae & Lactoria & fornasini & Thornback cowfish & & $\mathrm{x}$ & \\
\hline Ostraciidae & Ostracion & cubicus & Yellow boxfish & $\mathrm{x}$ & & \\
\hline Ostraciidae & Ostracion & meleagris & Whitespotted boxfish & $\mathrm{x}$ & & 1 \\
\hline Pegasidae & Eurypegasus & draconis & Short dragonfish & & & \\
\hline Pempheridae & Pempheris & bexillion & & $\mathrm{x}$ & & \\
\hline Pempheridae & Pempheris & flavicycla & & 76 & 20 & \\
\hline Pempheridae & Pempheris & spp. & & & & \\
\hline Pempheridae & Pempheris & spp. & & & & \\
\hline Pempheridae & Pempheris & spp. & & & & \\
\hline Pempheridae & Pempheris & spp. & & & & \\
\hline Pempheridae & Pempheris & spp. & & & & \\
\hline Pempheridae & Pempheris & spp. & & & & \\
\hline Pempheridae & Pempheris & spp. & & & & \\
\hline Pinguipedidae & Parapercis & hexophthalma & Speckled sandperch & 2 & & \\
\hline Platycephalidae & Papilloculiceps & longiceps & Indian Ocean crocodilefish & & & $\mathrm{x}$ \\
\hline Platycephalidae & Sunagocia & arenicola & Broadhead flathead & & & $\mathrm{x}$ \\
\hline Platycephalidae & Thysanophrys & chiltonae & Longsnout flathead & & & $\mathrm{x}$ \\
\hline Plotosidae & Plotosus & limbatus & Darkfin catfish & & & $\mathrm{x}$ \\
\hline Plotosidae & Plotosus & lineatus & Striped catfish & & $\mathrm{x}$ & $\mathrm{x}$ \\
\hline Pomacanthidae & Centropyge & multipinis & Brown dwarf-angelfish & 10 & & \\
\hline Pomacanthidae & Pomacanthus & chrysurus & African angelfish & 1 & $\mathrm{x}$ & $\mathrm{x}$ \\
\hline Pomacanthidae & Pomacanthus & imperator & Emperor angelfish & $\mathrm{x}$ & & $\mathrm{x}$ \\
\hline Pomacanthidae & Pomacanthus & semicirculatus & Semicircle angelfish & 5 & $\mathrm{x}$ & 5 \\
\hline Pomacanthidae & Pygoplites & diacanthus & Regal angelfish & $\mathrm{x}$ & & \\
\hline Pomacentridae & Abudefduf & notatus & Yellow-tail sergeant & & $\mathrm{x}$ & \\
\hline Pomacentridae & Abudefduf & septemfasciastus & Banded sergeant & & & $\mathrm{x}$ \\
\hline
\end{tabular}




\begin{tabular}{|c|c|c|c|c|c|c|}
\hline Pomacentridae & Abudefduf & sexfasciatus & Scissor sergeant & 77 & $\mathrm{x}$ & $\mathrm{x}$ \\
\hline Pomacentridae & Abudefduf & sordidus & Black-spot sergeant & & $\mathrm{x}$ & 5 \\
\hline Pomacentridae & Abudefduf & sparoides & False-eye sergeant & 23 & $\mathrm{x}$ & 2 \\
\hline Pomacentridae & Abudefduf & vaigiensis & Indo-Pacific sergeant & 4 & 21 & 29 \\
\hline Pomacentridae & Amphiprion & akallopisos & Skunk anemonefish & 1 & & \\
\hline Pomacentridae & Amphiprion & allardi & Allard's anemonefish & $\mathrm{x}$ & & 3 \\
\hline Pomacentridae & Chromis & dimidiata & Half and half chromis & 100 & & 30 \\
\hline Pomacentridae & Chromis & nigura & Blacktail chromis & 6 & & \\
\hline Pomacentridae & Chromis & ternatensis & Ternate chromis & $\mathrm{x}$ & & \\
\hline Pomacentridae & Chromis & viridis & Blue-green chromis & 40 & & \\
\hline Pomacentridae & Chromis & weberi & Weber's chromis & 15 & & \\
\hline Pomacentridae & Chrysiptera & annulata & Blackbarred demoiselle & & $\mathrm{x}$ & 15 \\
\hline Pomacentridae & Chrysiptera & biocellata & Twospot damsel & & 1 & \\
\hline Pomacentridae & Chrysiptera & brownriggi & Surge demoiselle & & 7 & 36 \\
\hline Pomacentridae & Chrysiptera & glauca & Grey demoiselle & & 1 & \\
\hline Pomacentridae & Chrysiptera & unimaculata & One spot demoiselle & & $\mathrm{x}$ & \\
\hline Pomacentridae & Dascyllus & aruanus & Humbug dascyllus & 2 & & \\
\hline Pomacentridae & Dascyllus & carneus & Indian dascyllus & 5 & & \\
\hline Pomacentridae & Dascyllus & trimaculatus & Three-spot dascyllus & 8 & $\mathrm{x}$ & 48 \\
\hline Pomacentridae & Neoglyphidodon & melas & Black damsel & $\mathrm{x}$ & & \\
\hline Pomacentridae & Neopomacentrus & azysron & Yellowtail demoiselle & 33 & & \\
\hline Pomacentridae & Neopomacentrus & cyanomos & Regal demoiselle & $\mathrm{x}$ & & \\
\hline Pomacentridae & Plectroglyphidodon & dickii & Dick's damsel & 6 & & \\
\hline Pomacentridae & Plectroglyphidodon & imparipennis & Brighteye damsel & & $\mathrm{x}$ & \\
\hline Pomacentridae & Plectroglyphidodon & johnstonianus & Johnston damsel & 7 & & \\
\hline Pomacentridae & Plectroglyphidodon & lacrymatus & Jewel damsel & 103 & & \\
\hline Pomacentridae & Pomacentrus & aquilus & Dark damsel & 3 & 5 & 58 \\
\hline Pomacentridae & Pomacentrus & baenschi & Baensch's damsel & 4 & & 1 \\
\hline Pomacentridae & Pomacentrus & caeruleus & Blue-yellow damsel & 2 & $\mathrm{x}$ & 3 \\
\hline Pomacentridae & Pomacentrus & pavo & Blue damsel & $\mathrm{x}$ & $\mathrm{x}$ & \\
\hline Pomacentridae & Pomacentrus & sulfureus & Sulphur damsel & 15 & & \\
\hline Pomacentridae & Pomacentrus & trichrous & Pailtail damsel & $\mathrm{x}$ & & \\
\hline Pomacentridae & Pomacentrus & trilineatus & Three-line damsel & & $\mathrm{x}$ & $\mathrm{x}$ \\
\hline Pomacentridae & Stegastes & fasciolatus & Pacific gregory & 2 & & \\
\hline Priacanthidae & Heteropriacanthus & cruentatus & Glasseye & $\mathrm{x}$ & & \\
\hline Priacanthidae & Priacanthus & hamrur & Goggle-eye & 2 & & \\
\hline Pseudochromidae & Pseudochromis & leucorhynchus & White-nose dottyback & & & $\mathrm{x}$ \\
\hline Rhinobatidae & Glaucostegus & halaci & Halavi ray & & & $\mathrm{x}$ \\
\hline Scaridae & Calotomus & carolinus & Stareye parrotfish & 39 & & \\
\hline Scaridae & Cetoscarus & bicolor & Bicolour parrotfish & $\mathrm{x}$ & & \\
\hline Scaridae & Chlorurus & atrilunula & Black crescent parrotfish & 7 & & \\
\hline Scaridae & Chlorurus & capistratoides & Pale bullethead parrotfish & 1 & & \\
\hline
\end{tabular}




\begin{tabular}{|c|c|c|c|c|c|c|}
\hline Scaridae & Chlorurus & sordidus & Bullethead parrotfish & 67 & & 12 \\
\hline Scaridae & Chlorurus & strongylocephalus & Indian Ocean steephead parrotfish & $\mathrm{x}$ & & \\
\hline Scaridae & Hipposcarus & harid & Indian Ocean longnose parrotfish & 1 & & \\
\hline Scaridae & Leptoscarus & vaigiensis & Seagrass parrotfish & 2 & $\mathrm{x}$ & 47 \\
\hline Scaridae & Scarus & frenatus & Bridled parrotfish & 16 & & \\
\hline Scaridae & Scarus & ghobban & Bluebarred parrotfish & 11 & & 1 \\
\hline Scaridae & Scarus & niger & Swarthy parrotfish & 8 & & \\
\hline Scaridae & Scarus & psittacus & Palenose parrotfish & 6 & & \\
\hline Scaridae & Scarus & rubroviolaceus & Redlip parrotfish & 12 & & \\
\hline Scaridae & Scarus & scaber & Dusky-capped parrotfish & $\mathrm{x}$ & & \\
\hline Scombridae & Rastrelliger & kanagurta & Striped mackerel & & & \\
\hline Scorpaenidae & Dendochirus & zebra & Zebra lionfish & & & \\
\hline Scorpaenidae & Parascorpaena & mossambica & Mozambique scorpionfish & & & $\mathrm{x}$ \\
\hline Scorpaenidae & Pterois & antennata & Spotfin lionfish & $\mathrm{x}$ & & \\
\hline Scorpaenidae & Pterois & miles & Common lionfish & 1 & $\mathrm{x}$ & \\
\hline Scorpaenidae & Pterois & mombasae & Mombasa lionfish & $\mathrm{x}$ & & \\
\hline Scorpaenidae & Pterois & radiata & Clearfin lionfish & $\mathrm{x}$ & $\mathrm{x}$ & \\
\hline Scorpaenidae & Scorpaenopsis & oxycephala & Tassled scorpionfish & $\mathrm{x}$ & 6 & \\
\hline Scorpaenidae & Scorpaenopsis & venosa & Raggy scorpionfish & $\mathrm{x}$ & & \\
\hline Scorpaenidae & Sebastapistes & cyanostigma & Yellowspotted scorpionfish & 12 & & \\
\hline Scorpaenidae & Sebastapistes & strongia & Barchin scorpionfish & & & $\mathrm{x}$ \\
\hline Scorpaenidae & Synanceia & verrucosa & Stonefish & & & \\
\hline Scorpaenidae & Taenianotus & triacanthus & Leaf scorpionfish & $\mathrm{x}$ & & \\
\hline Serranidae & Aethaloperca & rogaa & Redmouth grouper & $\mathrm{x}$ & & \\
\hline Serranidae & Cephalopholis & argus & Peacock grouper & 2 & & $\mathrm{x}$ \\
\hline Serranidae & Cephalopholis & leopardus & Leopard hind & $\mathrm{x}$ & & \\
\hline Serranidae & Cephalopholis & miniata & Coral hind & $\mathrm{x}$ & & \\
\hline Serranidae & Cephalopholis & sonnerati & Tomato grouper & $\mathrm{x}$ & & \\
\hline Serranidae & Dermatolepis & striolata & Smooth grouper & $\mathrm{x}$ & & \\
\hline Serranidae & Epinephelus & areolatus & Areolate grouper & $\mathrm{x}$ & & \\
\hline Serranidae & Epinephelus & caeruleopunctatus & Whitespotted grouper & & & \\
\hline Serranidae & Epinephelus & fasciatus & Blacktip grouper & 1 & & \\
\hline Serranidae & Epinephelus & fuscoguttatus & Brown-marbled grouper & $\mathrm{x}$ & & \\
\hline Serranidae & Epinephelus & lanceolatus & Giant grouper & & & $\mathrm{x}$ \\
\hline Serranidae & Epinephelus & longispinis & Longspine grouper & & & \\
\hline Serranidae & Epinephelus & macrospilos & Snubnose grouper & & & $\mathrm{x}$ \\
\hline Serranidae & Epinephelus & malabaricus & Malabar grouper & $\mathrm{x}$ & & \\
\hline Serranidae & Epinephelus & merra & Honeycomb grouper & $\mathrm{x}$ & & 2 \\
\hline Serranidae & Epinephelus & ongus & Specklefin grouper & $\mathrm{x}$ & & \\
\hline Serranidae & Epinephelus & spilotoceps & Foursaddle grouper & $\mathrm{x}$ & & \\
\hline Serranidae & Epinephelus & tauvina & Greasy grouper & & & $\mathrm{x}$ \\
\hline Serranidae & Epinephelus & tukula & Potato grouper & & & $\mathrm{x}$ \\
\hline
\end{tabular}




\begin{tabular}{|c|c|c|c|c|c|c|}
\hline Serranidae & Grammistes & sexlineatus & Six-striped soapfish & & 1 & $\mathrm{x}$ \\
\hline Serranidae & Plectropomus & laevis & Saddleback coralgrouper & $\mathrm{x}$ & & \\
\hline Serranidae & Plectropomus & punctatus & Marbled coralgrouper & 1 & & \\
\hline Serranidae & Pseudanthias & squamipinnis & Lyretail anthias & $\mathrm{x}$ & & \\
\hline Serranidae & Variola & louti & Lyretail grouper & $\mathrm{x}$ & & \\
\hline Signidae & Siganus & argenteus & Forktail rabbitfish & $\mathrm{x}$ & & $\mathrm{x}$ \\
\hline Signidae & Siganus & luridus & Squaretail rabbitfish & & & \\
\hline Signidae & Siganus & stellatus & Stellate rabbitfish & 3 & & 2 \\
\hline Signidae & Siganus & sutor & African whitespotted rabbitfish & 75 & $\mathrm{x}$ & 379 \\
\hline Soleidae & Pardachirus & marmoratus & Moses sole & & & 2 \\
\hline Solenostomidae & Solenostomus & cyanopterus & Ghost pipefish & & & \\
\hline Sphyraenidae & Sphyraena & barracuda & Great barracuda & & & $\mathrm{x}$ \\
\hline Sphyraenidae & Sphyraena & flavicauda & Yellowtail barracuda & & & $\mathrm{x}$ \\
\hline Sphyraenidae & Sphyraena & forsteri & Blackspot barracuda & & & 10 \\
\hline Sphyraenidae & Sphyraena & jello & Pickhandle barracuda & & & $\mathrm{x}$ \\
\hline Sphyraenidae & Sphyraena & putnamiae & Sawtooth barracuda & & & $\mathrm{x}$ \\
\hline Sphyraenidae & Sphyraena & qenie & Blackfin barracuda & & & $\mathrm{x}$ \\
\hline Sygnathidae & Corythoichthys & schultzi & Guilded pipefish & $\mathrm{x}$ & & \\
\hline Sygnathidae & Doryhamphus & excisus & Bluestripe pipefish & & & \\
\hline Sygnathidae & Hippocampus & hystrix & Thorny seahorse & & & \\
\hline Sygnathidae & Micrognathus & andersonii & Short-nose pipefish & & $\mathrm{x}$ & \\
\hline Synodontidae & Synodus & dermatogenys & Sand lizardfish & $\mathrm{x}$ & & 1 \\
\hline Synodontidae & Saurida & gracilis & Graceful lizardfish & $\mathrm{x}$ & 1 & \\
\hline Tetraodontidae & Arothron & hispidus & Whitespotted puffer & & & 2 \\
\hline Tetraodontidae & Arothron & immaculatus & Immaculate puffer & & & $\mathrm{x}$ \\
\hline Tetraodontidae & Arothron & mappa & Globe puffer & & & $\mathrm{x}$ \\
\hline Tetraodontidae & Arothron & meleagris & Guineafowl puffer & & & $\mathrm{x}$ \\
\hline Tetraodontidae & Arothron & nigropunctatus & Blackspotted puffer & 4 & & \\
\hline Tetraodontidae & Arothron & stellatus & Star puffer & & & 1 \\
\hline Tetraodontidae & Canthigaster & amboinensis & Ambon toby & & & $\mathrm{x}$ \\
\hline Tetraodontidae & Canthigaster & bennetti & Bennett's toby & 6 & $\mathrm{x}$ & 20 \\
\hline Tetraodontidae & Canthigaster & janthinopera & Honeycomb toby & $\mathrm{x}$ & & \\
\hline Tetraodontidae & Canthigaster & petersii & Peters toby & 5 & 1 & \\
\hline Tetraodontidae & Canthigaster & valentini & Blacksaddle toby & 9 & $\mathrm{x}$ & 1 \\
\hline Theraponidae & Terapon & jarbua & Crescent-banded grunter & & $\mathrm{x}$ & \\
\hline Torpedinidae & Torpedo & sinuspersici & Marbled electric ray & $\mathrm{x}$ & & \\
\hline Zanclidae & Zanclus & cornutus & Moorish idol & 19 & & 1 \\
\hline
\end{tabular}




\section{Appendix 2b-Species lists for Echinoderms, Molluscs and Crustacea}

\begin{tabular}{|c|c|c|c|c|c|c|c|}
\hline Phylum & Class & Genus & Species & English & Reef & Intertidal & Subtidal \\
\hline Echinodermata & Asteroidea & Culcita & schmideliana & Cake star & $\mathrm{x}$ & $\mathrm{x}$ & $\mathrm{x}$ \\
\hline Echinodermata & Asteroidea & Dactylosaster & cylindricus & & 1 & & \\
\hline Echinodermata & Asteroidea & Euretaster & cribrosus & Dimple star & & & $\mathrm{x}$ \\
\hline Echinodermata & Asteroidea & Leiaster & coriaceus & Mottled star & & $\mathrm{x}$ & $\mathrm{x}$ \\
\hline Echinodermata & Asteroidea & Linckia & laevigata & Blue star & 3 & $\mathrm{x}$ & \\
\hline Echinodermata & Asteroidea & Linckia & multifora & Irregular arm star & & $\mathrm{x}$ & \\
\hline Echinodermata & Asteroidea & Monachaster & sanderi & Pygmy plate star & $\mathrm{x}$ & 1 & \\
\hline Echinodermata & Asteroidea & Nardoa & variolata & Red dot star & $\mathrm{x}$ & $\mathrm{x}$ & \\
\hline Echinodermata & Asteroidea & Protoeaster & lincki & Red crown star & $\mathrm{x}$ & $\mathrm{x}$ & \\
\hline Echinodermata & Echinoidea & Astropyga & radiata & Radiant urchin & $\mathrm{x}$ & $\mathrm{x}$ & $\mathrm{x}$ \\
\hline Echinodermata & Echinoidea & Diadema & savingyi & Blue star urchin & 23 & 1 & \\
\hline Echinodermata & Echinoidea & Diadema & setosum & Anal spot urchin & 5 & $\mathrm{x}$ & \\
\hline Echinodermata & Echinoidea & Echinometra & matthaei & Rockpool urchin & 44 & 275 & \\
\hline Echinodermata & Echinoidea & Echinostrephus & molaris & Burrowing urchin & 198 & & \\
\hline Echinodermata & Echinoidea & Echinothrix & calamaris & Black and white urchin & 18 & $\mathrm{x}$ & \\
\hline Echinodermata & Echinoidea & Echinothrix & diadema & Reef urchin & 257 & 161 & \\
\hline Echinodermata & Echinoidea & Eucidaris & metularia & Rough pencil urchin & & & $\mathrm{x}$ \\
\hline Echinodermata & Echinoidea & Toxopneustes & pileolus & Flower urchin & 2 & $\mathrm{x}$ & $\mathrm{x}$ \\
\hline Echinodermata & Echinoidea & Tripneustes & gratillia & Seagrass urchin & $\mathrm{x}$ & 11 & $\mathrm{x}$ \\
\hline Echinodermata & Holothurioidea & Actinopyga & echinites & Hedgehog cucumber & & $\mathrm{x}$ & \\
\hline Echinodermata & Holothurioidea & Actinopyga & mauritiana & White belly cucumber & $\mathrm{x}$ & 1 & \\
\hline Echinodermata & Holothuroidea & Actinopyga & miliaris & Military cucumber & & $\mathrm{x}$ & \\
\hline Echinodermata & Holothuroidea & Bohadschia & $s p$. & Red dot cucumber & & $\mathrm{x}$ & \\
\hline Echinodermata & Holothuroidea & Bohadschia & subrubra & Patch cucumber & $\mathrm{x}$ & & \\
\hline Echinodermata & Holothuroidea & Holothuria & atra & Common black cucumber & 1 & & \\
\hline Echinodermata & Holothuroidea & Holothuria & scabra & Tasty cucumber & & & $\mathrm{x}$ \\
\hline Echinodermata & Holothuroidea & Patinapta & crosslandi & Worm cucumber & & $\mathrm{x}$ & \\
\hline Echinodermata & Holothuroidea & Pearsonothuria & graeffei & Black palp cucumber & $\mathrm{x}$ & & \\
\hline Echinodermata & Holothuroidea & Synapta & maculata & Seagrass cucumber & & & $\mathrm{x}$ \\
\hline Echinodermata & Ophiuroidea & Amphiura & dejectoides & Brittlestar & & 41 & \\
\hline Echinodermata & Ophiuroidea & Ophiocentrus & dilalatus & Brittlestar & $\mathrm{x}$ & & \\
\hline Echinodermata & Ophiuroidea & Ophiocoma & erinaceus & Brittlestar & 2 & & \\
\hline Echinodermata & Ophiuroidea & Ophiocoma & scolopendrina & Brittlestar & 8 & 268 & \\
\hline Echinodermata & Ophiuroidea & Ophiomastix & venosa & Brittlestar & & 7 & \\
\hline Mollusca & Bivalvia & Chione & toreuma & & & 1 & \\
\hline Mollusca & Bivalvia & Tridacna & maxima & Burrowing giant clam & 2 & 1 & \\
\hline Mollusca & Bivalvia & Tridacna & sqaumosa & Fluted giant clam & 53 & $\mathrm{x}$ & \\
\hline Mollusca & Cephalopoda & Octopus & cyanea & Common reef octopus & 1 & $\mathrm{x}$ & $\mathrm{x}$ \\
\hline
\end{tabular}




\begin{tabular}{|c|c|c|c|c|c|c|c|}
\hline Mollusca & Gastropoda & Asteronotus & cespitosus & & & $\mathrm{x}$ & \\
\hline Mollusca & Gastropoda & Ceritium & nodulosum & & & 3 & \\
\hline Mollusca & Gastropoda & Charonia & tritonis & Giant triton & $\mathrm{x}$ & & \\
\hline Mollusca & Gastropoda & Conus & arenatus & Sand dusted coneshell & & 10 & \\
\hline Mollusca & Gastropoda & Conus & catus & Cat coneshell & 1 & 2 & \\
\hline Mollusca & Gastropoda & Conus & coronatus & Crowned coneshell & & 1 & \\
\hline Mollusca & Gastropoda & Conus & ebraeus & $\begin{array}{l}\text { Black and white } \\
\text { coneshell }\end{array}$ & & 88 & \\
\hline Mollusca & Gastropoda & Conus & litteratus & Lettered coneshell & & 4 & \\
\hline Mollusca & Gastropoda & Conus & lividis & Livid coneshell & 2 & 18 & \\
\hline Mollusca & Gastropoda & Conus & rattus & Rat coneshell & & 3 & \\
\hline Mollusca & Gastropoda & Conus & striatellus & Coneshell & & 2 & \\
\hline Mollusca & Gastropoda & Chromodoris & spp. & Nudibranch & $\mathrm{x}$ & & \\
\hline Mollusca & Gastropoda & Clypeomorus & bifasciatus & & & 3 & \\
\hline Mollusca & Gastropoda & Cypraea & tigris & Leopard cowrie & & $\mathrm{x}$ & $\mathrm{x}$ \\
\hline Mollusca & Gastropoda & Cypraecassis & rufa & Bullmouth helmetshell & & $\mathrm{x}$ & $\mathrm{x}$ \\
\hline Mollusca & Gastropoda & Dolabella & auricularia & Wedge seahare & & $\mathrm{x}$ & \\
\hline Mollusca & Gastropoda & Drupa & fusconigra & & & $\mathrm{x}$ & \\
\hline Mollusca & Gastropoda & Drupella & rugosa & Rugose drupe & & 58 & \\
\hline Mollusca & Gastropoda & Engina & mendicaria & Bumblebee shell & 1 & 261 & \\
\hline Mollusca & Gastropoda & Flabellina & exoptata & Desirable flabellina & 2 & & \\
\hline Mollusca & Gastropoda & Giberellus & giberellus & Humpback conch & & 2 & \\
\hline Mollusca & Gastropoda & Glossodoris & hikuerensis & Nudibranch & $\mathrm{x}$ & & \\
\hline Mollusca & Gastropoda & Halgerda & formosa & Nudibranch & 9 & & \\
\hline Mollusca & Gastropoda & Halgerda & tessellata & Nudibranch & $\mathrm{x}$ & & \\
\hline Mollusca & Gastropoda & Halgerda & wasinensis & Nudibranch & $\mathrm{x}$ & & \\
\hline Mollusca & Gastropoda & Hastula & lanceata & & & 2 & \\
\hline Mollusca & Gastropoda & Hypselodoris & regina & Nudibranch & & & $\mathrm{x}$ \\
\hline Mollusca & Gastropoda & Jorunna & rubsecens & Nudibranch & $\mathrm{x}$ & & \\
\hline Mollusca & Gastropoda & Lambis & $\begin{array}{l}\text { chiragra } \\
\text { (arthritica) }\end{array}$ & Arthritic spider conch & 5 & & \\
\hline Mollusca & Gastropoda & Lambis & lambis & Spider conch & 1 & & \\
\hline Mollusca & Gastropoda & Lambis & truncata & Giant spider conch & $\mathrm{x}$ & & \\
\hline Mollusca & Gastropoda & Littoraria & scabra & Mangrove periwinkle & & 2 & \\
\hline Mollusca & Gastropoda & Littoraria & undulata & Periwinkle & 1 & 1 & \\
\hline Mollusca & Gastropoda & Mauritia & histrio & Harlequin cowrie & & 2 & \\
\hline Mollusca & Gastropoda & Mirta & paupercula & Miter shell & & & \\
\hline Mollusca & Gastropoda & Monetaria & annulus & Goldring cowrie & & 5 & \\
\hline Mollusca & Gastropoda & Morula & granulata & Mulberry shell & 2 & & \\
\hline Mollusca & Gastropoda & Nerita & albicilla & Blotched nerite & & 111 & \\
\hline Mollusca & Gastropoda & Ovula & ovum & Common egg cowrie & $\mathrm{x}$ & & \\
\hline Mollusca & Gastropoda & Phyllidia & varicosa & Nudibranch & 3 & $\mathrm{x}$ & \\
\hline Mollusca & Gastropoda & Phyllidiella & meandrina & Nudibranch & $\mathrm{x}$ & $\mathrm{x}$ & \\
\hline
\end{tabular}




\begin{tabular}{|c|c|c|c|c|c|c|c|}
\hline Mollusca & Gastropoda & Phyllidiella & zeylonica & Nudibranch & 7 & $\mathrm{x}$ & \\
\hline Mollusca & Gastropoda & Phyllidiopsis & striata & Nudibranch & $\mathrm{x}$ & & $\mathrm{x}$ \\
\hline Mollusca & Gastropoda & Pleuroploca & trapezium & Tulip shell & & & $\mathrm{x}$ \\
\hline Mollusca & Gastropoda & Pollia & fumosus & Smoky goblet & & 9 & \\
\hline Mollusca & Gastropoda & Pollia & undodsus & Waved goblet & & 1 & \\
\hline Mollusca & Gastropoda & Pteraeolidea & ianthina & Blue dragon school & $\mathrm{x}$ & & \\
\hline Mollusca & Gastropoda & Rhinoclaris & sinensis & Chinese cerith & 1 & & \\
\hline Mollusca & Gastropoda & Terebra & dimidiata & Giraffe screwshell & & & $\mathrm{x}$ \\
\hline Mollusca & Gastropoda & Thuridilla & indopacifica & Nudibranch & $\mathrm{x}$ & & \\
\hline Mollusca & Gastropoda & Vasum & ceramicum & Ceramic vaseshell & & 1 & \\
\hline Mollusca & Gastropoda & Vasum & rhinocerus & Rhinocerus vaseshell & & 2 & \\
\hline Mollusca & Gastropoda & Vasum & turbinellus & Black and white vaseshell & 3 & 4 & \\
\hline Mollusca & Gastropoda & Vexillium & rugosum & Ribbed miter & & 2 & \\
\hline Mollusca & Gastropoda & Volema & paradisiaca & Pear melongena & & 1 & \\
\hline Mollusca & Polyplacophora & Acanthopleura & gemmata & Splashzone chiton & & 5 & \\
\hline Crustacea & Anomura & Dardanus & deformis & Anemone hermit crab & & $\mathrm{x}$ & \\
\hline Crustacea & Anomura & Dardanus & lagopodes & Hairy hermit crab & $\mathrm{x}$ & & \\
\hline Crustacea & Anomura & Dardanus & megistos & Bluespot hermit crab & $\mathrm{x}$ & $\mathrm{x}$ & \\
\hline Crustacea & Anomura & Neopetrolisthes & maculatus & Anemone crab & & $\mathrm{x}$ & \\
\hline Crustacea & Brachyura & Calappa & hepatica & Box crab & & & $\mathrm{x}$ \\
\hline Crustacea & Brachyura & Cardisoma & carnifex & Red land crab & & $\mathrm{x}$ & \\
\hline Crustacea & Brachyura & Eriphia & smithi & Redeye rockpool crab & & $\mathrm{x}$ & \\
\hline Crustacea & Brachyura & Estisus & slendidus & Red crab & $\mathrm{x}$ & & \\
\hline Crustacea & Brachyura & Graspus & tenuicrustatus & Surge crab & & $\mathrm{x}$ & \\
\hline Crustacea & Brachyura & Lydia & annulipes & Striped stone crab & & $\mathrm{x}$ & \\
\hline Crustacea & Brachyura & Ocypode & ceratophthalmus & Horny eyed ghostcrab & & $\mathrm{x}$ & \\
\hline Crustacea & Brachyura & Ocypode & cordimanus & Smooth handed ghostcrab & & $\mathrm{x}$ & \\
\hline Crustacea & Brachyura & Ocypode & ryderi & Pink ghostcrab & & $\mathrm{x}$ & \\
\hline Crustacea & Brachyura & Percnon & planissium & Flat coral crab & $\mathrm{x}$ & & \\
\hline Crustacea & Brachyura & Tetralia & glaberrima & Acropora coral crab & $\mathrm{x}$ & & \\
\hline Crustacea & Brachyura & Trapezia & rufopunctata & Spotted coral crab & $\mathrm{x}$ & & \\
\hline Crustacea & Caridea & Hymenocera & picta & Harlequin shrimp & & $\mathrm{x}$ & \\
\hline Crustacea & Caridea & Rhynchocinetes & durbanensis & Jagged shrimp & $\mathrm{x}$ & & \\
\hline Crustacea & Caridea & Stenopus & hispidus & Banded cleaner shrimp & $\mathrm{x}$ & $\mathrm{x}$ & \\
\hline Crustacea & Palinura & Panulirus & versicolor & Painted spiny lobster & $\mathrm{x}$ & $\mathrm{x}$ & \\
\hline Crustacea & Stomatopoda & Gonodactylus & chiragar & Sandy mantis shrimp & & $\mathrm{x}$ & \\
\hline Crustacea & Stomatopoda & Gonodactylus & platysoma & Spotted mantis shrimp & & $\mathrm{x}$ & \\
\hline Crustacea & Stomatopoda & Odontodactylus & scyllarus & Peacock mantis shrimp & $\mathrm{x}$ & & \\
\hline
\end{tabular}




\section{Appendix 2c-Genus list for Scleractinian corals}

\begin{tabular}{|c|c|c|c|}
\hline Family & Genus & Reef & Intertidal \\
\hline \multirow[t]{4}{*}{ Acroporidae } & Acropora & $\mathrm{x}$ & $\mathrm{x}$ \\
\hline & Alveopora & & $\mathrm{x}$ \\
\hline & Astreopora & $\mathrm{x}$ & $\mathrm{x}$ \\
\hline & Montipora & $\mathrm{x}$ & \\
\hline \multirow[t]{3}{*}{ Agarciidae } & Gardineroseris & $\mathrm{x}$ & \\
\hline & Leptoseris & $\mathrm{x}$ & \\
\hline & Pavona & $\mathrm{x}$ & $\mathrm{x}$ \\
\hline \multirow[t]{2}{*}{ Coscinaraeaidae } & Anomastrea & & $\mathrm{x}$ \\
\hline & Coscinaraea & $\mathrm{x}$ & $\mathrm{x}$ \\
\hline Dendrophyllidae & Turbinaria & $\mathrm{x}$ & \\
\hline Euphyllidae & Plerogyra & $\mathrm{X}$ & \\
\hline \multirow[t]{11}{*}{ Faviidae } & Cyphastrea & $\mathrm{x}$ & \\
\hline & Echinopora & $\mathrm{x}$ & \\
\hline & Favia & $\mathrm{x}$ & $\mathrm{x}$ \\
\hline & Favites & $\mathrm{x}$ & $\mathrm{x}$ \\
\hline & Goniastrea & $\mathrm{x}$ & $\mathrm{x}$ \\
\hline & Leptastrea & $\mathrm{x}$ & $\mathrm{x}$ \\
\hline & Leptoria & $\mathrm{x}$ & \\
\hline & Montastrea & $\mathrm{x}$ & \\
\hline & Oulophyllia & $\mathrm{x}$ & \\
\hline & Platygyra & $\mathrm{x}$ & $\mathrm{x}$ \\
\hline & Plesiastrea & $\mathrm{x}$ & \\
\hline \multirow[t]{4}{*}{ Fungiidae } & Ctenactis & $\mathrm{x}$ & \\
\hline & Fungia & $\mathrm{x}$ & \\
\hline & Herpolitha & $\mathrm{x}$ & \\
\hline & Podabacia & $\mathrm{x}$ & \\
\hline \multirow[t]{2}{*}{ Merulinidae } & Hydnophora & $\mathrm{x}$ & $\mathrm{x}$ \\
\hline & Merulina & $\mathrm{x}$ & \\
\hline \multirow[t]{4}{*}{ Mussidae } & Acanthastrea & $\mathrm{x}$ & \\
\hline & Blastomussa & $\mathrm{x}$ & \\
\hline & Lobophyllia & $\mathrm{x}$ & \\
\hline & Symphyllia & $\mathrm{x}$ & \\
\hline Oculinidae & Galaxea & $\mathrm{x}$ & \\
\hline \multirow[t]{3}{*}{ Pectiniidae } & Echinophyllia & $\mathrm{x}$ & \\
\hline & Mycedium & $\mathrm{x}$ & \\
\hline & Pectinia & $\mathrm{x}$ & \\
\hline Pocilloporidae & Pocillopora & $\mathrm{x}$ & \\
\hline \multirow[t]{2}{*}{ Poritidae } & Goniopora & $\mathrm{x}$ & \\
\hline & Porites & $\mathrm{x}$ & $\mathrm{x}$ \\
\hline Siderastreidae & Psammocora & $\mathrm{x}$ & \\
\hline
\end{tabular}

